\title{
A Large Endoplasmic Reticulum-Resident Pool of TRPM1 in Retinal ON-Bipolar Cells
}

\author{
DiD Melina A. Agosto, ${ }^{1}$ Ivan A. Anastassov, ${ }^{1{ }^{*}}$ Michael A. Robichaux, ${ }^{1}$ and Theodore G. Wensel ${ }^{1}$
}

DOI:http://dx.doi.org/10.1523/ENEURO.0143-18.2018

${ }^{1}$ Verna and Marrs McLean Department of Biochemistry and Molecular Biology, Baylor College of Medicine, Houston, TX 77030

\begin{abstract}
The chemical signal of light onset, a decrease in glutamate release from rod and cone photoreceptors, is processed by a postsynaptic G protein signaling cascade in ON-bipolar cells (BPCs). The metabotropic glutamate receptor mGluR6, along with other cascade elements, is localized synaptically at the BPC dendritic tips. The effector ion channel protein transient receptor potential melastatin-1 (TRPM1), in contrast, is located not only at the dendritic tips but also in BPC bodies and axons. Little is known about the intracellular localization of TRPM1, or its trafficking route to the dendritic tip plasma membrane. Recombinant TRPM1 expressed in mammalian cells colocalized with endoplasmic reticulum (ER) markers, with little or none detected at the plasma membrane. In mouse retina, somatic TRPM1 was similarly intracellular, and not at the plasma membrane. Labeling of ER membranes by expression of a fluorescent marker showed that in BPCs the ER extends into axons and dendrites, but not dendritic tips. In cell bodies, TRPM1 colocalized with the ER, and not with the Golgi apparatus. Fluorescence protease protection (FPP) assays with TRPM1-GFP fusions in heterologous cells revealed that the $\mathrm{N}$ and $\mathrm{C}$ termini are both accessible to the cytoplasm, consistent with the transmembrane domain topology of related TRP channels. These results indicate that the majority of TRPM1 is present in the ER, from which it can potentially be transported to the dendritic tips as needed for ON light responses. The excess of ER-resident TRPM1 relative to the amount needed at the dendritic tips suggests a potential new function for TRPM1 in the ER.
\end{abstract}

Key words: bipolar cell; protein trafficking; secretory pathway; TRPM1

\section{Significance Statement}

Retinal bipolar cells (BPCs) of the ON subtype detect signals from both rod and cone photoreceptors and are required for dim light vision. Little is known about the secretory pathway in these cells, or the trafficking of synaptic signal cascade proteins to their destination at the dendritic tip plasma membrane. The ion channel protein transient receptor potential melastatin-1 (TRPM1) is required for the depolarizing light response of ON-BPCs. However, in addition to its postsynaptic location at the BPC dendritic tips, TRPM1 is also present in cell bodies and axons. Our results show that somatic TRPM1 is intracellular and located in the endoplasmic reticulum (ER), and not at the plasma membrane, suggesting that plasma membrane insertion occurs specifically at the dendrites or dendritic tips.

\section{Introduction}

At the synapses between photoreceptors and downstream bipolar cells (BPCs) in the retina, signals are di- vided into two channels: the ON channel, which responds to light onset, and the OFF channel, which responds to dark onset. Rod BPCs are all in the ON channel. In rod 
and cone ON-BPCs, glutamate released from photoreceptor terminals is detected by a metabotropic glutamate receptor signaling cascade. The glutamate receptor, mGluR6, signals via the heterotrimeric $G$ protein $G_{o}$, which in turn gates a transduction channel by an unknown mechanism (for review, see Martemyanov and Sampath, 2017). Transient receptor potential melastatin-1 (TRPM1) is required for channel function (Audo et al., 2009; Li et al., 2009; Morgans et al., 2009; Shen et al., 2009; Van Genderen et al., 2009; Koike et al., 2010b), but it is not known if it is sufficient for formation of the $\mathrm{G}_{\mathrm{o}}$-sensitive channel (Lambert et al., 2011; Agosto et al., 2014; Schneider et al., 2015; Martemyanov and Sampath, 2017). In the dark, tonic release of glutamate activates mGluR6, keeping the channel closed; at light onset, decrease in glutamate release and deactivation of mGluR6 lead to channel opening and membrane depolarization.

Retinal BPC bodies reside in the distal part of the inner nuclear layer; dendrites extend into the outer plexiform layer, where the dendritic tips form synapses with photoreceptor terminals, and the axon extends into the inner plexiform layer, where it forms synapses with amacrine or ganglion cells (for review, see Dunn and Wong, 2014; Fig. $1 A)$. Like other secondary neurons, retinal BPCs are highly polarized and maintain specialized postsynaptic machinery specifically in dendritic tips. Disruption or knock-out of other synaptic components, namely, mGluR6 (Cao et al., 2011; Xu et al., 2012; Gregg et al., 2014), nyctalopin (NYX; Pearring et al., 2011; Gregg et al., 2014), LRIT3 (Neuillé et al., 2015), or ELFN1 (Cao et al., 2015), reduces or eliminates TRPM1 accumulation at the dendritic tips. However, localization of mGluR6 (Morgans et al., 2009; Koike et al., 2010b; Peachey et al., 2012a) and NYX (Pearring et al., 2011; Gregg et al., 2014) appear normal in TRPM1 knock-out mice, suggesting that these proteins do not require interaction with TRPM1 for trafficking. Consistent with this, a recent study of TRPM1 and mGluR6 during postnatal development found that mGluR6 appears at the dendritic tips earlier than TRPM1, and that these proteins are likely trafficked independently of each other (Anastassov et al., 2017). Despite these findings, protein trafficking in the BPC dendrites is still poorly understood, and little is known about the location of secretory pathway organelles in these cells.

This work was supported by National Institutes of Health (NIH) Grants R01-EY007981/EY007981-S1, R01-EY025218, and R01-EY026545 (to T.G.W.), F32-EY020067 (to M.A.A.), F32-EY024815 (to I.A.A.), and F32EY027171 (to M.A.R.); by a Knights Templar Eye Foundation Pediatric Ophthalmology Career-Starter Grant (to M.A.A.); by the Welch Foundation Grant Q0035; and by the Monoclonal Antibody/Recombinant Protein Expression Shared Resource at Baylor College of Medicine with funding from NIH Cancer Center Support Grant P30-CA125123.

*I. A. Anastassov's present address: Department of Ophthalmology, University of California, San Francisco, CA 94143.

Correspondence should be addressed to Melina A. Agosto, Department of Biochemistry and Molecular Biology, BCM-125, Baylor College of Medicine, 1 Baylor, Plaza, Houston, TX 77030, E-mail: agosto@bcm.edu.

DOI:http://dx.doi.org/10.1523/ENEURO.0143-18.2018

Copyright (C) 2018 Agosto et al.

This is an open-access article distributed under the terms of the Creative Commons Attribution 4.0 International license, which permits unrestricted use, distribution and reproduction in any medium provided that the original work is properly attributed.
Although the transduction channel activity of TRPM1 is likely restricted to the synapses at BPC dendritic tips, where other participants of the pathway are localized (Nomura et al., 1994; Masu et al., 1995; Morgans et al., 2006, 2007; Peachey et al., 2012b; Orlandi et al., 2013), more than half of TRPM1 is found in BPC bodies (Morgans et al., 2009; Koike et al., 2010b; Agosto et al., 2018; Fig. 1A). There have been some data suggesting that somatic TRPM1 is at least partially intracellular (Pearring et al., 2011; Xu et al., 2012), but the subcellular localization is unknown, as is the location of plasma membrane insertion. In this study, we have shown that the endoplasmic reticulum (ER) in ON-BPCs extends into axons and dendrites, and that TRPM1 in cell bodies is intracellular and colocalized with the ER. In addition, we have confirmed that the intracellular topology of ER-resident TRPM1 conforms to that of the superfamily of ion channels to which it belongs.

\section{Materials and Methods}

\section{Animals}

WT C57BL/6 mice were obtained from the Baylor College of Medicine Center for Comparative Medicine, and WT CD-1 mice were purchased from Charles River Laboratories (RRID: IMSR_CRL: 22). Nob3 mice (Grm6 ${ }^{\text {nob3; }}$ Maddox et al., 2008) were obtained from The Jackson Laboratory (RRID: IMSR_JAX: 016883). Absence of the $\mathrm{Pde}^{\mathrm{rd}} \mathrm{b}^{\mathrm{rd}}$ allele was confirmed by genotyping as previously described (Giménez and Montoliu, 2001), and absence of the Crb1 ${ }^{\text {rd8 }}$ allele (Mattapallil et al., 2012) was confirmed by PCR amplifying and sequencing the surrounding region of genomic DNA. All immunofluorescence microscopy experiments were performed with WT C57BL/6 mice aged 4-12 weeks, except experiments involving subretinal injections, for which CD-1 mice were used as described below. Mice of either sex were used for all experiments. All procedures were approved by the Baylor College of Medicine Animal Care and Use Committee.

\section{Cells}

Human embryonic kidney (HEK293) cells were obtained from the ATCC (\#CRL-1573, RRID: CVCL_0045) and maintained in DMEM (Corning) supplemented with $10 \%$ FBS (HyClone or Sigma). For fluorescence protease protection (FPP) assays, HEK293 cells were a gift from Michael Xi Zhu (The University of Texas Health Science Center at Houston, Houston, TX). Chinese hamster ovary $(\mathrm{CHO})$ cells were maintained in Ham's F12 Nutrient Mixture (HyClone), or DMEM/F12 50/50 (Corning), with 10\% FBS.

\section{Primary antibodies}

Antibodies, concentrations used, and validation information are shown in Table 1. Generation of monoclonal antibodies with full-length mouse mGluR6 has been described, and clone 312 was used previously (and validated) for Western blotting (Agosto et al., 2018). In this study, we used clone 366, which, unlike clone 312, performs well in retina immunostaining; clone 366 is validated in Figure 4. TRPM1, mGluR6, and 1D4 antibodies were 
A

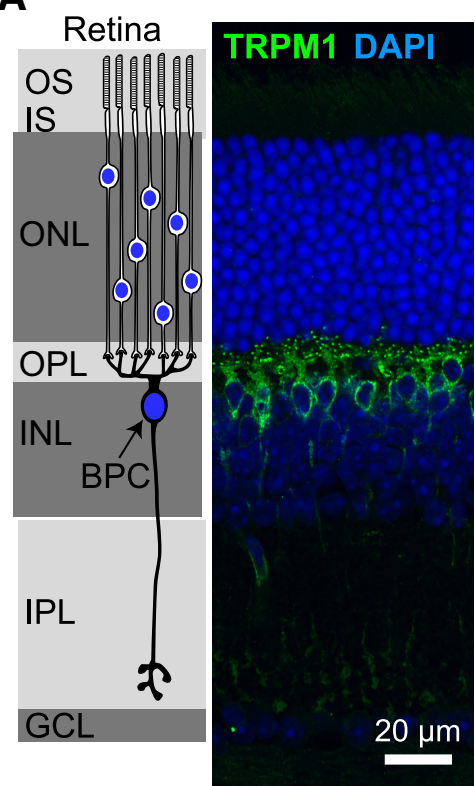

B
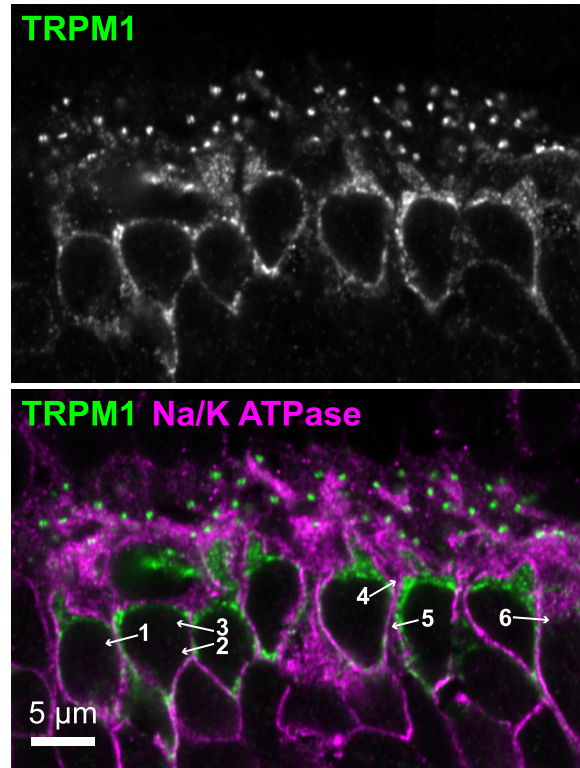
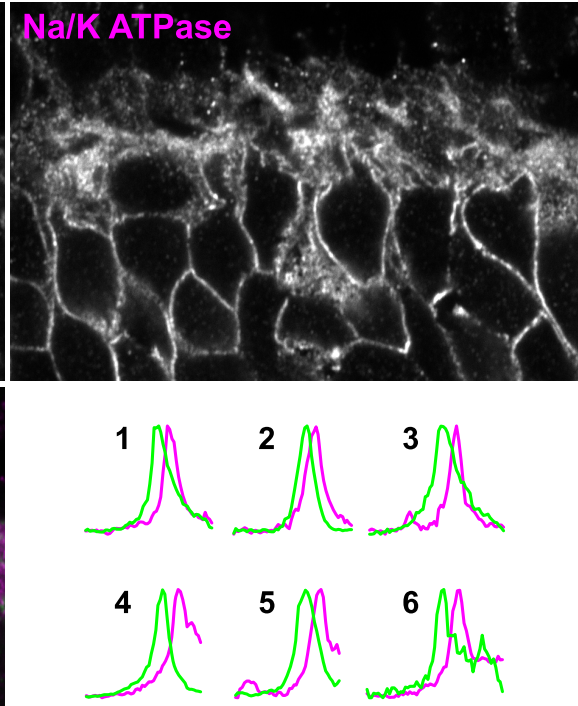

\section{STORM}
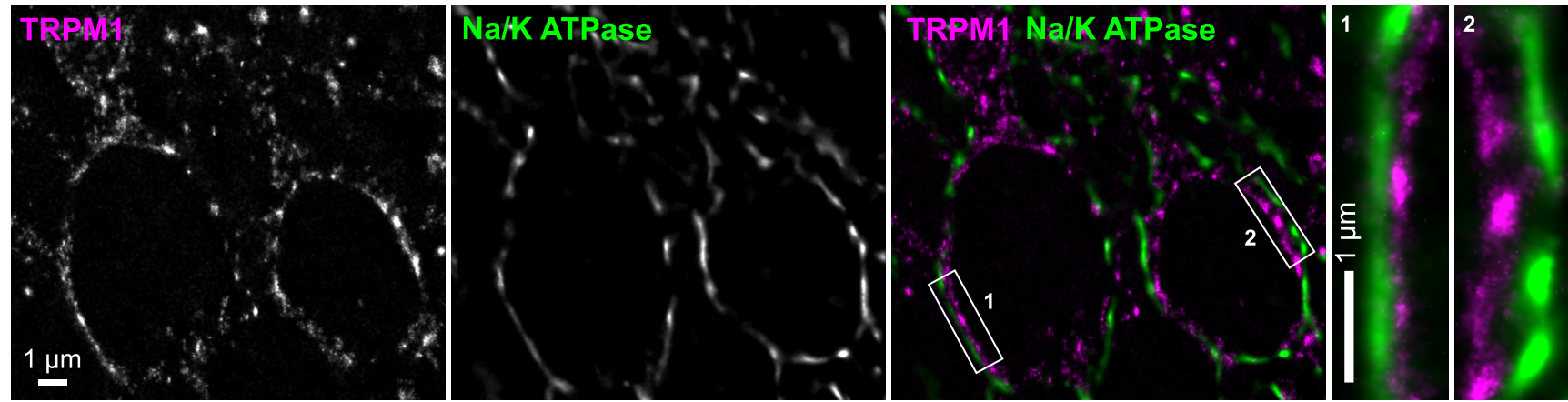

\section{Confocal}

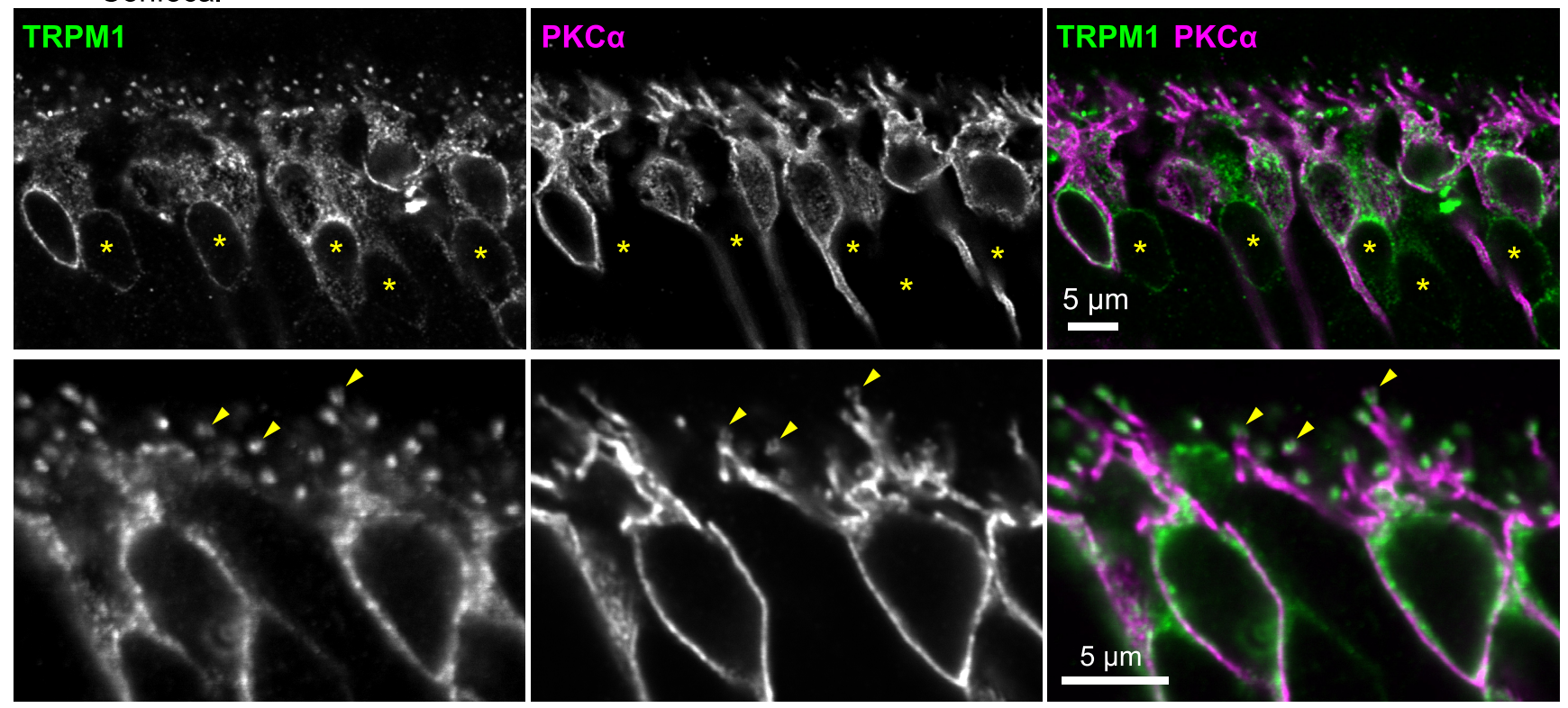

Figure 1. TRPM1 is intracellular in ON-BPC bodies. $\boldsymbol{A}$, Diagram of rod photoreceptors synapsing onto a rod BPC, alongside TRPM1 immunostaining (green) of a mouse retina section. OS, outer segments; IS, inner segments; ONL, outer nuclear layer; OPL, outer plexiform layer; INL, inner nuclear layer; IPL, inner plexiform layer; GCL, ganglion cell layer. B, Retina sections were immunostained with antibodies for TRPM1 (green) and the plasma membrane marker $\mathrm{Na}^{+} / \mathrm{K}^{+}$ATPase (magenta). Intensity profiles were measured 


\section{continued}

along lines indicated by the arrows on the merged image and are shown normalized to the maximum height. $\boldsymbol{C}$, STORM reconstructions of retina sections immunostained for TRPM1 (magenta) and $\mathrm{Na}^{+} / \mathrm{K}^{+}$ATPase (green). Boxes show the regions magnified on the right. $\boldsymbol{D}$, Retina sections immunostained for TRPM1 (green) and cytoplasmic protein PKC $\alpha$ (magenta). TRPM1 staining is also present in PKC $\alpha$-negative cone BPC bodies (asterisks). Magnified images are shown on the bottom, with arrowheads indicating dendritic tips.

purified from hybridoma cultures as previously described (Agosto et al., 2014).

\section{Expression constructs}

Cloning of TRPM1 (isoform C, NP 001034193.2) and NYX (NP_775591.1) from mouse retina was previously described (Agosto et al., 2014, 2018). DsRed cDNA was obtained from pDsRed-monomer-C1 (Clontech). Constructs for transfection of $\mathrm{HEK}$ and $\mathrm{CHO}$ cells were all cloned in pCDNA3.1(+) using Kpnl and Notl, and consisted of free GFP or DsRed; untagged TRPM1; TRPM1 with a C-terminal 1D4 tag or N-terminal HA tag; EGFP-

Table 1. Primary antibody sources, concentrations used, and validation information

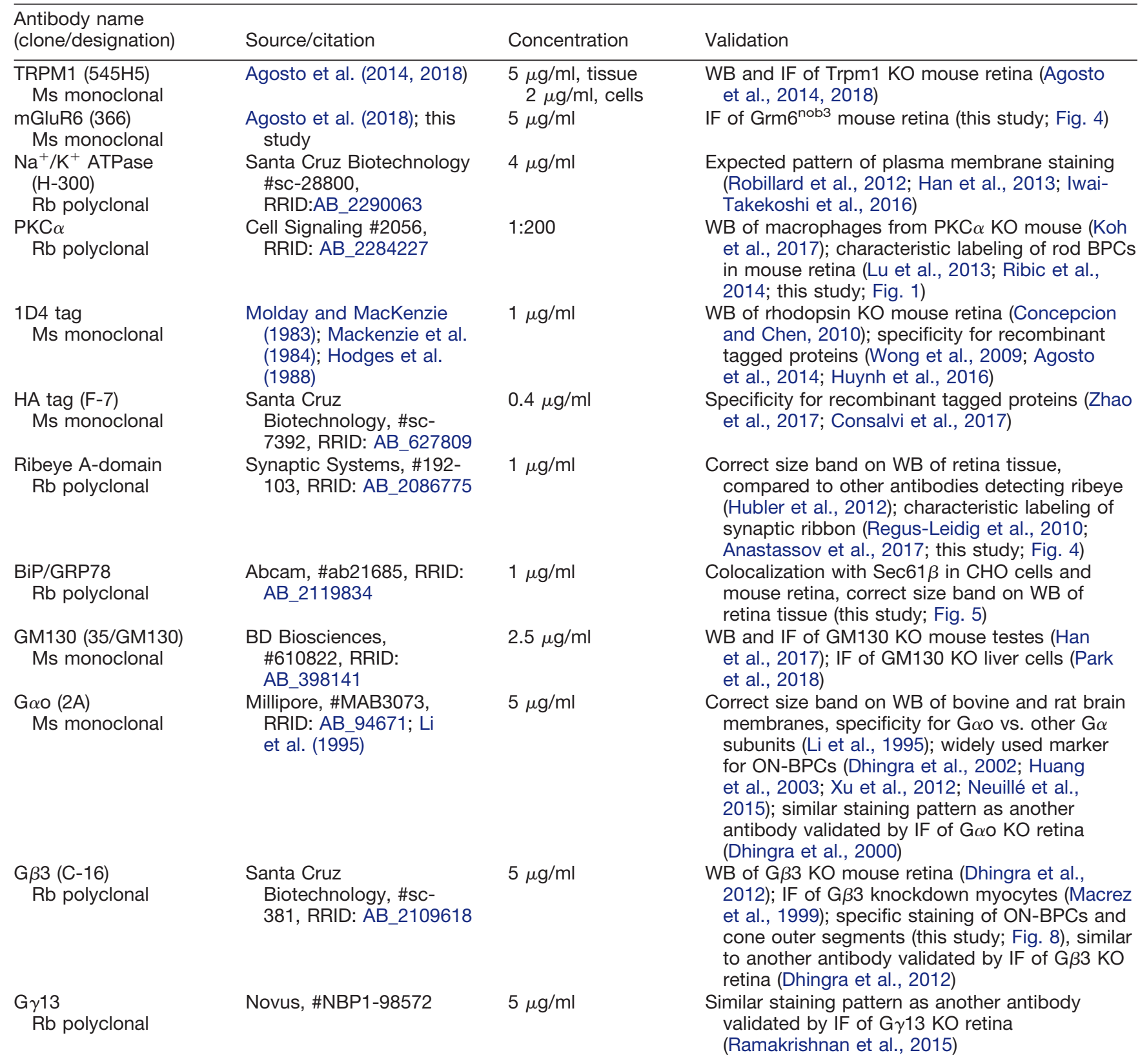


TRPM1 and TRPM1-EGFP fusions containing linkers GGSGG and APVAT, respectively; EGFP-NYX with EGFP behind the signal sequence (NYX[1-19]-EGFP-GGGSGGGNYX[20-476]); NYX-EGFP (NYX-GGGSGGG-EGFP); or dsRed-NYX (Nyx[1-19]-DsRed-Nyx[20-476]). An EmeraldSec61 $\beta$ construct with CMV promoter (mEmerald-Sec61-C18) was obtained from Michael Davidson (Addgene plasmid \#54249). pGrm6P-Emerald-Sec61 $\beta$ was constructed by cloning Emerald-Sec61 $\beta$ into a plasmid containing the Grm6 promoter 200-bp critical region and SV40 enhancer (Kim et al., 2008), derived from Addgene plasmid \#18817, a gift from Connie Cepko, by removing the GFP, IRES, and alkaline phosphatase portions of its sequence.

\section{Subretinal injection and electroporation}

DNA for injection was prepared using a Qiafilter Maxiprep kit (QIAGEN) and dissolved in water. Injections and electroporations were performed as previously described (Matsuda and Cepko, 2004, 2008). Briefly, left eyelids of CD-1 P0 mouse pups were opened with an incision along the future edge of the eyelid. Pilot holes were made in the sclera (postlimbus) with a 30-G needle, followed by positioning of a 33-G blunt injection needle into the subretinal space. Approximately $450 \mathrm{nl}$ of pGrm6PEmerald-Sec61 $\beta$ plasmid DNA (2.5-3 $\mathrm{mg} / \mathrm{ml})$ in PBS with $0.1 \%$ Fast Green dye were injected using a microinjector (UMP3 Microsyringe Injector and Micro4 Controller, World Precision Instruments) set at $130 \mathrm{nl} / \mathrm{s}$. Five $50-\mathrm{ms}$ pulses of $80 \mathrm{~V}$, separated by $950-\mathrm{ms}$ intervals, were applied across the eyes using custom tweezers with 7-mm diameter electrodes and an ECM 830 square wave electroporator (BTX Harvard Apparatus). Eyecup dissections were performed approximately four weeks later.

\section{Retina immunostaining}

Intact eyes from room-light-adapted animals were used. No obvious differences in TRPM1 localization were observed in light- and dark-adapted animals. Eyes were fixed in 4\% PFA in PBS for 45-60 min, washed extensively in PBS, then cryoprotected in $30 \%$ sucrose in PBS overnight at $4^{\circ} \mathrm{C}$. The cornea and lens were removed, and eyecups were embedded in OCT; 8- to 20- $\mu \mathrm{m}$ cryostat sections were adhered to Superfrost Plus slides (VWR or Fisher) or coverslips coated with $100 \mu \mathrm{g} / \mathrm{ml}$ poly-Dlysine (PDL). Sections were postfixed in 2-4\% PFA for 10 min, washed in PBS, and blocked for $2 \mathrm{~h}$ at room temperature (RT) in PBS with 10\% donkey serum, 5\% BSA, and $0.2 \%$ Triton $\mathrm{X}-100$. Samples were incubated overnight at $4^{\circ} \mathrm{C}$ with primary antibodies diluted in blocking buffer, washed in PBS, then incubated at RT for $2 \mathrm{~h}$ with secondary antibodies (donkey anti-mouse-Alexa Fluor 488 and goat or donkey anti-mouse-Alexa Fluor 555, or goat anti-mouse-IgG2B-Alexa Fluor 555 and goat anti-mouseIgG1-Alexa Fluor 488; Invitrogen/Thermo Fisher) diluted to 8 $\mu \mathrm{g} / \mathrm{ml}$ in blocking buffer, then washed in PBS and mounted with Prolong Gold (Invitrogen/Thermo Fisher).

For super-resolution stochastic optical reconstruction microscopy (STORM), \#1.5 square coverslips were acid washed, then coated with $100 \mu \mathrm{g} / \mathrm{ml}$ PDL for $1 \mathrm{~h}$, washed in water, and air dried. 8- $\mu \mathrm{m}$ cryostat sections were adhered to the coverslips, which were then glued with epoxy to the bottom (outside) of 35-mm hole-bottom dishes. Immunostaining was performed as described above, except that secondary antibodies were goat anti-mouse[F(ab')2]-Alexa Fluor 647 and goat-anti-rabbit[F(ab')2]-Alexa Fluor 555 (Invitrogen/Thermo Fisher). Before imaging, labeled sections were covered with imaging buffer [50 mM Tris $(\mathrm{pH} 8) 10 \mathrm{mM}$ $\mathrm{NaCl}, 0.56 \mathrm{mg} / \mathrm{ml}$ glucose oxidase (Sigma), $34 \mu \mathrm{g} / \mathrm{ml}$ catalase (Roche or Sigma), 10\% (w/v) glucose, 15 mM cysteamine hydrochloride, and 10\% VECTASHIELD H-1000 (Vector Laboratories); Dempsey et al., 2011] and a second coverslip sealed with epoxy. The VECTASHIELD in the imaging buffer enables the photoswitching behavior of Alexa Fluor 555 (Olivier et al., 2013).

\section{Retina dissociation and immunostaining}

Three mice were used for each experiment. Retinas were dissected in dissection/dissociation buffer [DD; 97.5\% Hanks' balanced salt solution, $0.11 \mathrm{mg} / \mathrm{ml}$ sodium pyruvate, $0.1 \%$ (w/v) glucose, $9.8 \mathrm{mM}$ HEPES $\mathrm{pH} 7.3$; Beaudoin et al., 2012] and washed three times in DD. Retinas were then suspended in $1 \mathrm{ml}$ DMEM with $2 \mathrm{mg} / \mathrm{ml}$ freshly-added papain (Worthington) and incubated with the lid open in a $37^{\circ} \mathrm{C} 5 \% \mathrm{CO}_{2}$ incubator for $30 \mathrm{~min}$. The papain was inactivated by washing twice with $1 \mathrm{ml}$ DMEM + $10 \%$ FBS. Cells in $1 \mathrm{ml}$ fresh DMEM + 10\% FBS were then dissociated by sharply tapping the tube $\sim 10$ times on a hard surface (Berntson et al., 2003). Large debris were allowed to settle, and $150 \mu$ l of the supernatant were spread onto Superfrost Plus slides with a wide-orifice pipet tip, then allowed to adhere for $15 \mathrm{~min}$ at RT. $150 \mu \mathrm{l}$ of $4 \%$ PFA in PBS was added directly to the cells, and incubated for an additional $15 \mathrm{~min}$, then slides were washed in PBS and immunostained as described below for cultured cells.

\section{Cell transfection and immunostaining}

Cells in 24-well plates were transfected with $0.1 \mu \mathrm{g}$ mEmerald-Sec61-C-18 and 0.5-0.7 $\mu \mathrm{g}$ pCDNA3.1-TRPM1 plasmid DNA using Lipofectamine 2000 (Thermo Fisher) according to the manufacturer's instructions. The next day, cells were briefly trypsinized and replated on PDLcoated (HEK cells) or uncoated ( $\mathrm{CHO}$ cells) coverslips. At $\sim 48$ h post-transfection, cells were fixed with $2 \%$ PFA in PBS for $10 \mathrm{~min}$, washed in PBS, blocked/permeabilized with PBS $+1 \%$ BSA $+0.1 \%$ Triton X-100 (PBSAT) for 15 min, labeled with primary antibody in PBSAT for 45-60 $\mathrm{min}$, followed by secondary antibodies $2-4 \mu \mathrm{g} / \mathrm{ml}$ in PBSAT for $30 \mathrm{~min}$. For some experiments, $\mathrm{CHO}$ cells were transfected on coverslips, and labeled after $\sim 24 \mathrm{~h}$ without replating. Coverslips were mounted with Prolong Gold.

\section{Confocal microscopy and image processing}

Images were acquired with a TCS-SP5 laser scanning confocal microscope (Leica) using a $63 \times$ oil immersion objective (Leica, HC PL APO CS2 63.0×, numerical aperture 1.40). Alexa Fluor 555 and Alexa Fluor 488 were detected in sequential mode with a $543 \mathrm{~nm}$ HeNe laser and $488 \mathrm{~nm}$ argon laser, respectively, with imaging parameters set to avoid cross-talk between the channels. Images were acquired with few or no saturated pixels. For figures, images were processed in ImageJ (NIH) and/or 
A

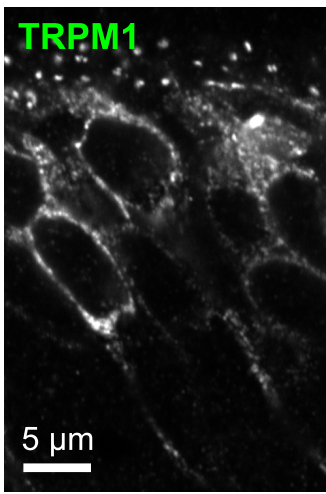

B

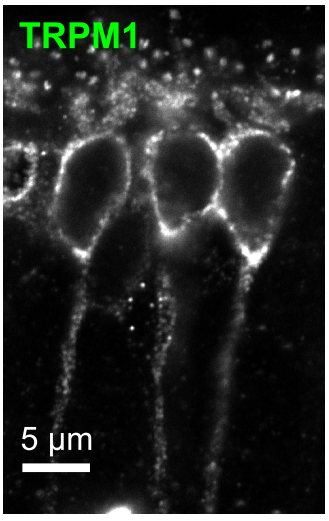

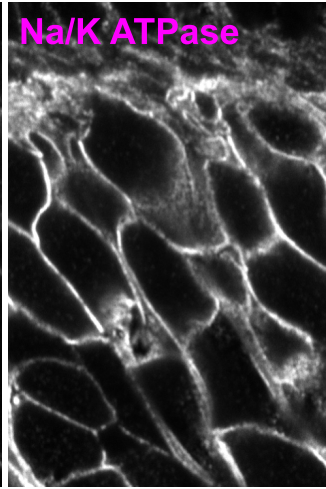
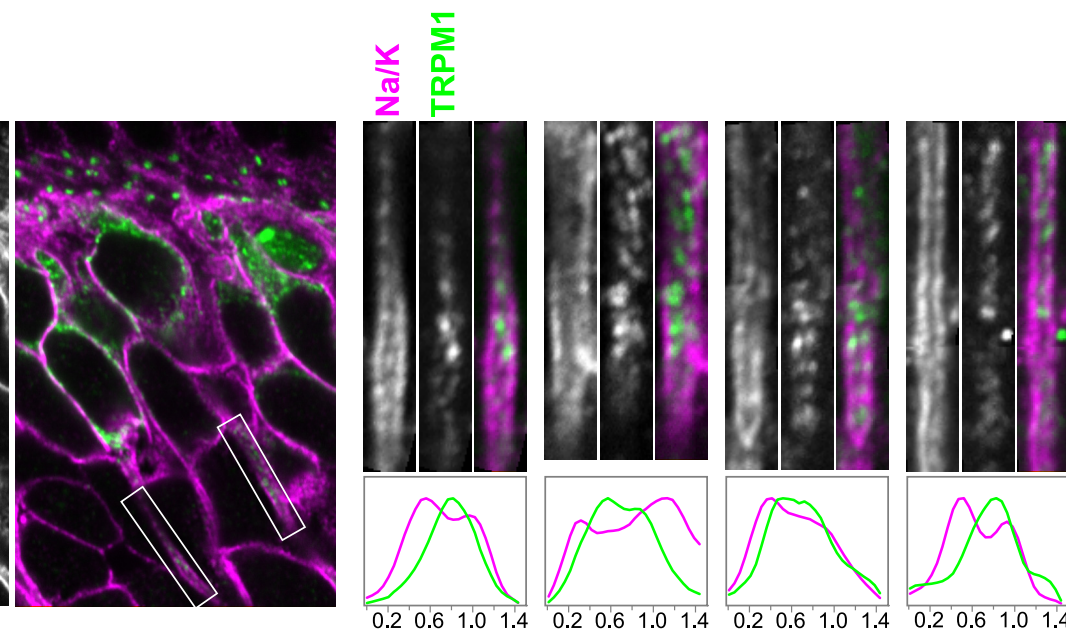
ช

Distance $(\mu \mathrm{m})$
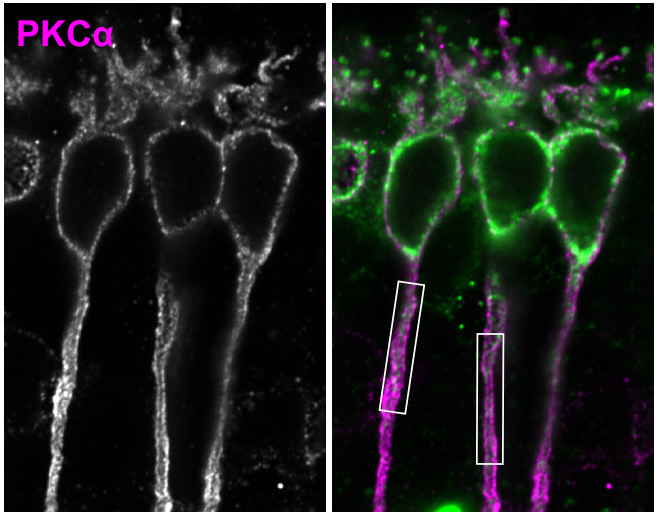
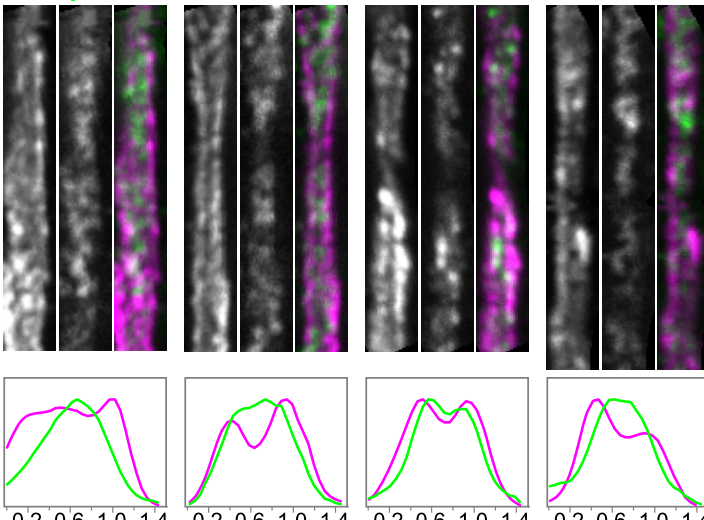

$\begin{array}{llllll}0.2 & 0.6 & 1.0 & 1.4\end{array}$
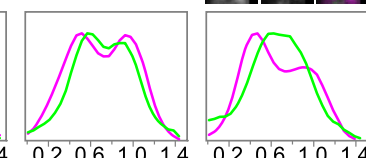

Distance $(\mu \mathrm{m})$

Figure 2. TRPM1 is intracellular in ON-BPC axons. Retina sections were labeled with $\mathrm{TRPM} 1$ (green) and antibodies to $\mathrm{Na}^{+} / \mathrm{K}^{+}$ ATPase to mark the plasma membrane $(\boldsymbol{A})$ or PKC $\alpha$ to mark the cytoplasm (B; magenta). Regions containing axons were straightened, and normalized column average intensity profiles are shown. Two axons from the example images at left (regions indicated by boxes) as well as two axons from other images are shown.

Photoshop (Adobe) to apply pseudocolors and adjust the minimum and maximum input levels, maintaining a linear slope. All images are single optical sections unless indicated as projections.

Line scans were determined from raw images in ImageJ using 1 px-wide lines and the "plot profile" tool. Cropped raw images of axons were straightened in ImageJ using 30 px-wide segmented lines and the "straighten" tool, and column average line scans were measured using the straightened axon image and plot profile. Profiles are shown normalized to the maximum intensity.

\section{STORM imaging and data analysis}

Images were acquired with a Nikon N-STORM system, with a 100× oil immersion TIRF objective (CFI Apo TIRF, numerical aperture 1.49). $561 \mathrm{~nm}$ and $647 \mathrm{~nm}$ solid-state lasers were used at maximum power to induce photoswitching of Alexa Fluor 555 and Alexa Fluor 647, respectively, without the use of an activator fluorophore (Bock et al., 2007; Heilemann et al., 2008); $512 \times 512$ px fields $(160 \mathrm{~nm} / \mathrm{px})$ were imaged with an Andor iXON DU 897
EMCCD camera and a quad cube filter (Chroma, zt405/ 488/561/640 m-TRF); 20,000-50,000 18-ms exposure frames ( $\sim 56$ frames/s) were acquired for each channel, with alternating sequential activation. A cylindrical lens typically used for 3D-STORM was used, although data analysis was confined to 2D (see below). X-Y warp calibration was employed to correct chromatic aberration between channels. 2D-STORM reconstructions were performed with Nikon NIS Elements Ar Analysis software as previously described (Robichaux et al., 2017), except using minimum and maximum photon counts of 200-500 and 10,000, respectively. After reconstruction, density filters were applied to remove background events.

\section{Western blotting}

Preparation of total retina lysate and Western blotting were as previously described (Agosto et al., 2018). Blots were incubated overnight with BiP antibody (Table 1), 1 $\mu \mathrm{g} / \mathrm{ml}$, then with horseradish-peroxidase conjugated antirabbit (Jackson ImmunoResearch), $0.16 \mu \mathrm{g} / \mathrm{ml}$, followed 

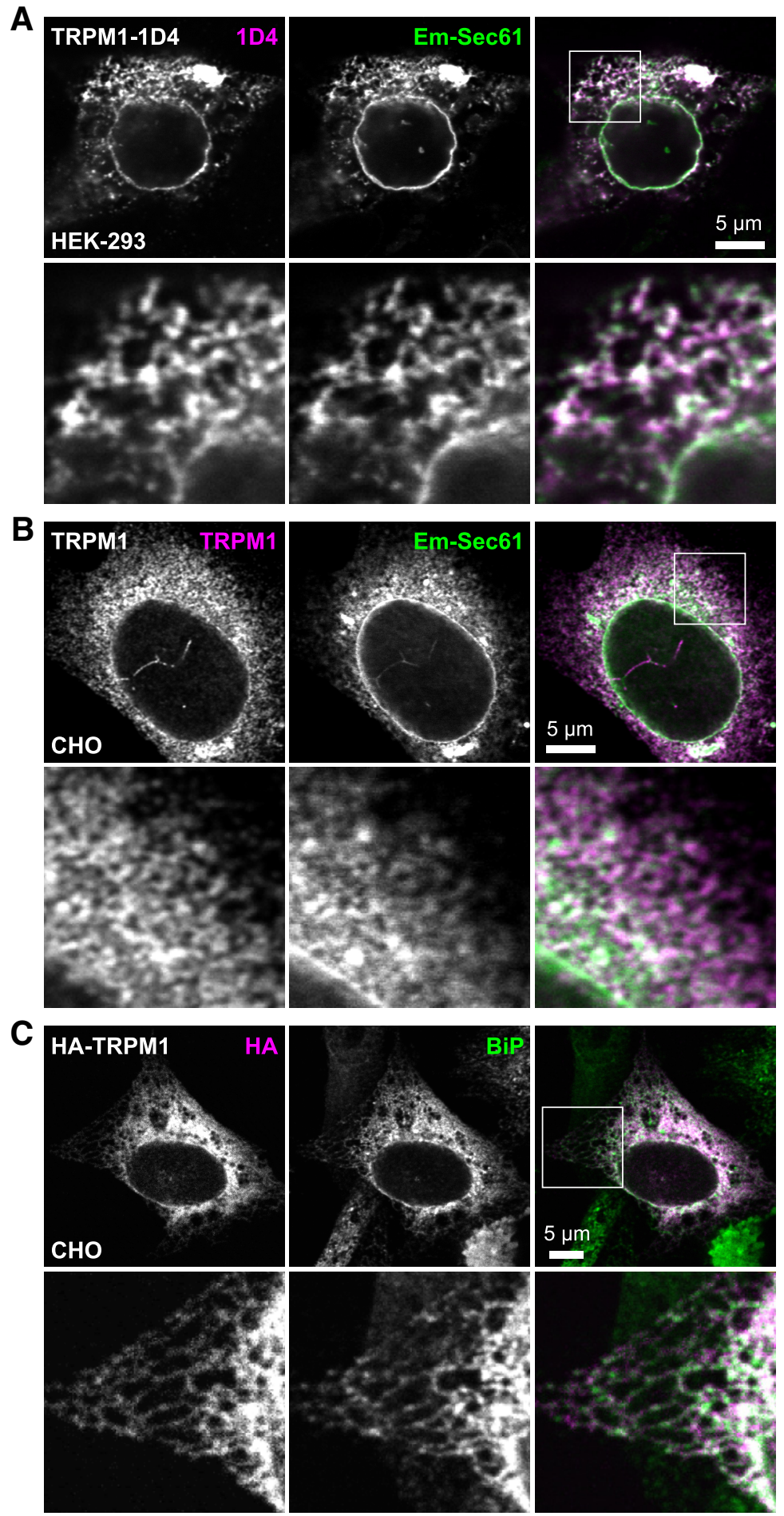

Figure 3. TRPM1 colocalizes with the ER in heterologous cells. $\boldsymbol{A}, \boldsymbol{B}, \mathrm{HEK} 293(\boldsymbol{A})$ or $\mathrm{CHO}(\boldsymbol{B})$ cells were transiently transfected with 1D4 epitope-tagged $(\boldsymbol{A})$ or untagged $(\boldsymbol{B})$ TRPM1 and Emerald-Sec61 (green). Cells were labeled with 1D4 (A) or TRPM1 antibody (B; magenta). C, $\mathrm{CHO}$ cells were transiently transfected with HA-tagged TRPM1, and labeled with HA (magenta) and BiP (green) antibodies.

by HyGLO (Denville Scientific) or SuperSignal West Pico (Thermo) chemiluminescent substrate, and exposed to film.

\section{FPP assay}

HEK293 cells in 24-well plates were transfected with $0.4 \mu \mathrm{g}$ EGFP-NYX or NYX-EGFP, or $0.6 \mu \mathrm{g}$ EGFP-TRPM1 or TRPM1-EGFP, along with 0.2-0.4 $\mu \mathrm{g}$ dsRed; or $0.2 \mu \mathrm{g}$ GFP and $0.4 \mu \mathrm{g}$ dsRed-NYX; or $0.4 \mu \mathrm{g}$ dsRed-NYX and $0.4 \mu \mathrm{g}$ NYX-EGFP, using Lipofectamine 2000. The next day, cells were briefly trypsinized and replated in eightwell Lab-Tek II chambered coverglasses which had previously been coated with $100 \mu \mathrm{g} / \mathrm{ml}$ PDL. Assays were 
A

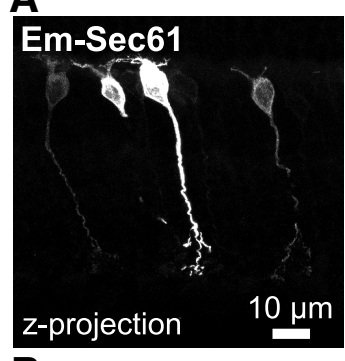

B

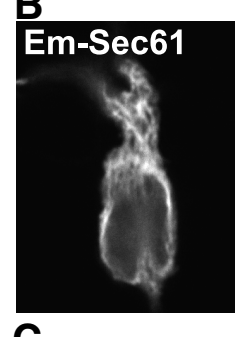

C
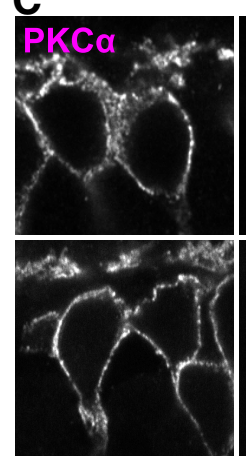
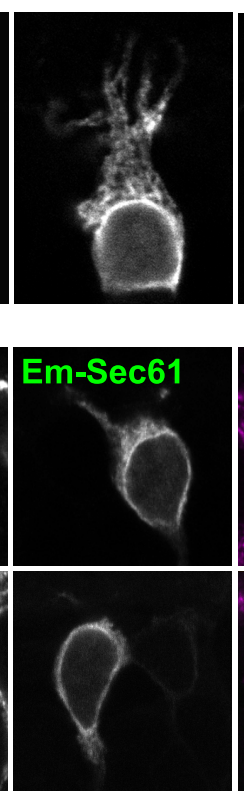

D

(1)
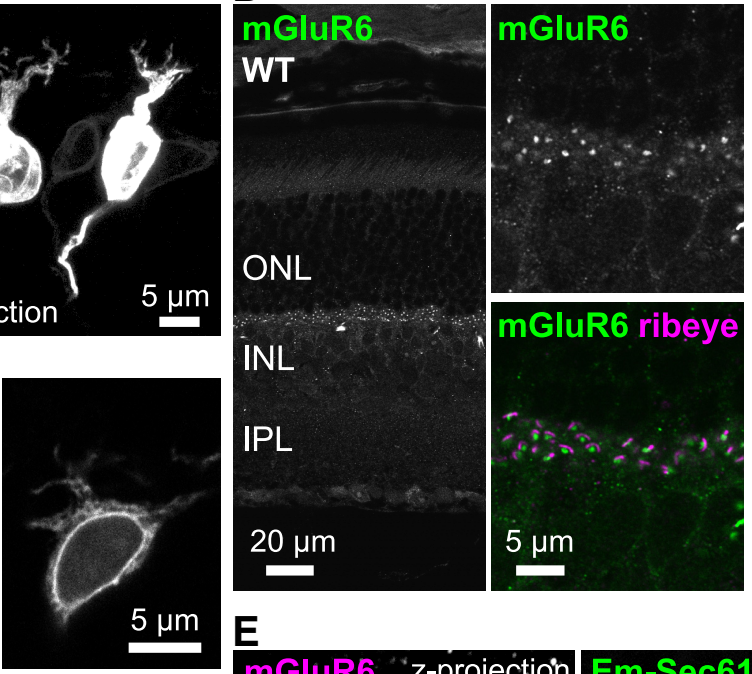

E
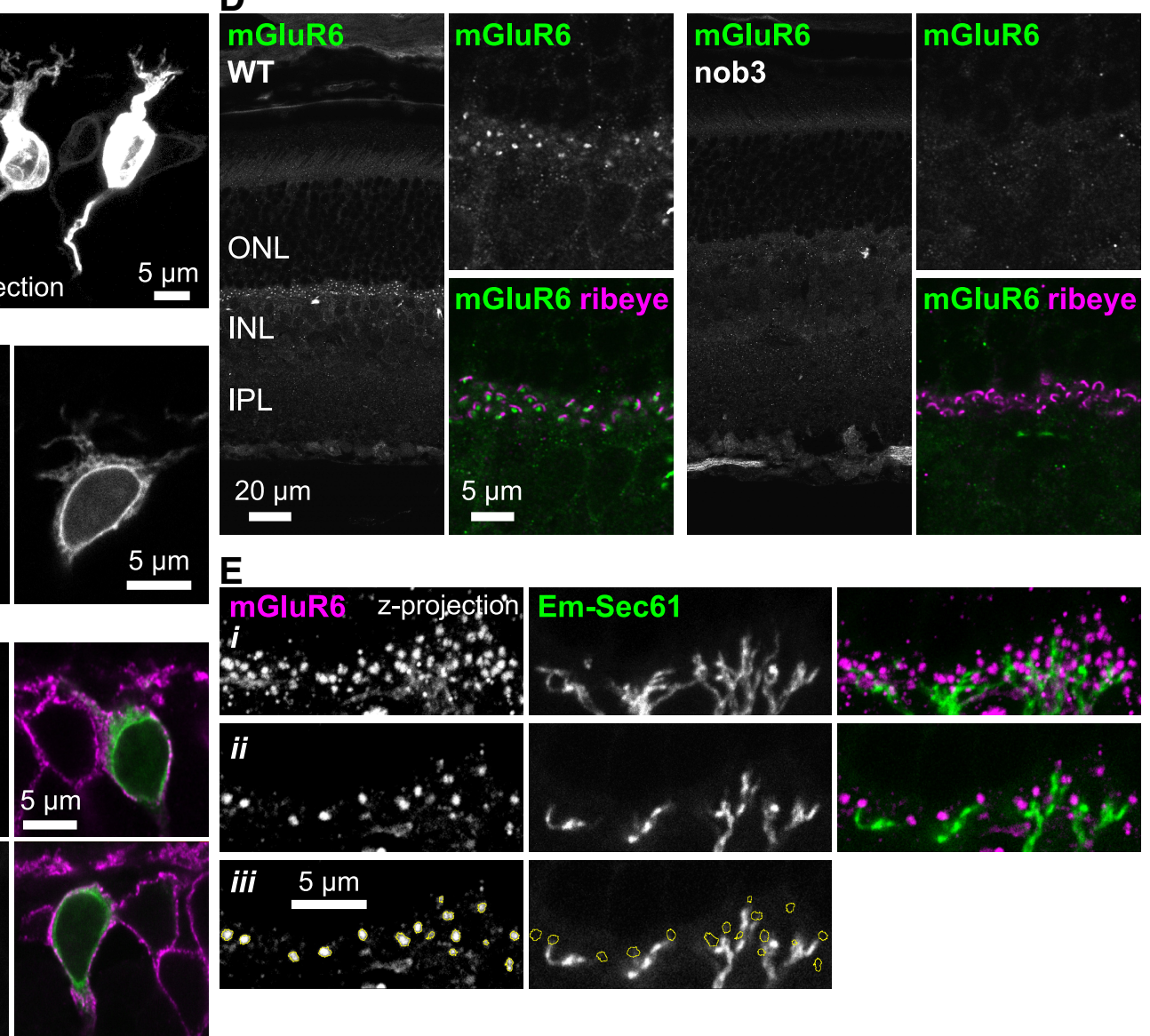

Figure 4. Localization of ER in ON-BPCs. Emerald-Sec61 $\beta$ was expressed in ON-BPCs by subretinal injection and electroporation of plasmid DNA using the ON-BPC-specific Grm6 promoter. A, Z-projections of confocal stacks are shown oversaturated to highlight localization of Emerald-Sec61 in axons and dendrites. B, Magnified views of cell bodies. $\boldsymbol{C}$, Immunostaining sections from injected retinas shows that in cell bodies, PKC $\alpha$ is located peripherally to the ER. $\boldsymbol{D}$, Validation of new mGluR6 mAb. Retina sections from WT (left) and nob3 (right) mice were labeled with mGluR6 antibody (green) and costained for presynaptic ribbon protein ribeye (magenta) to mark the location of synapses. Dendritic tip mGluR6 labeling is present in WT but not nob3 retinas. $\boldsymbol{E}$, Sections from injected retinas were immunostained with the mGluR6 mAb (magenta), revealing that Emerald-Sec61 $\beta$ in dendrites does not extend into the dendritic tip puncta. (i) Z-projection of confocal stack. (ii) Single optical slice from the same field. (iii) Same images as in (ii), with the location of mGluR6 puncta outlined in yellow.

performed at RT, $\sim 48-52 \mathrm{~h}$ post-transfection. Immediately before imaging, wells were washed three times with RT KHM buffer ( $110 \mathrm{mM}$ potassium acetate, $2 \mathrm{mM} \mathrm{MgCl}_{2}$, and $20 \mathrm{mM}$ HEPES; $\mathrm{pH}$ 7.2) and left in $200 \mu \mathrm{l} \mathrm{KHM}$ for the assay. Digitonin (5\% solution from Invitrogen/Thermo Fisher) was heated to $95^{\circ} \mathrm{C}$ to dissolve and diluted in $\mathrm{KHM}$ immediately before use. UltraClean Proteinase K $(20 \mathrm{mg} /$ $\mathrm{ml}$, Mo Bio) was diluted in KHM immediately before use. Images were acquired with the TCS-SP5 laser scanning confocal microscope (Leica) using the $63 \times$ oil immersion objective described above, set to scan every $30 \mathrm{~s}$. Following the 1-min scan, $200 \mu \mathrm{l}$ of $200 \mu \mathrm{M}$ digitonin was added to the well. Following the 2-min scan, $400 \mu \mathrm{l}$ of $\mathrm{KHM}$ (no protease control) or $100 \mu \mathrm{g} / \mathrm{ml}$ proteinase $\mathrm{K}$ was added to the well. In most experiments, fields containing many cells $(512 \times 512 \mathrm{px}, 481.5 \mathrm{~nm} / \mathrm{px})$ were imaged, and individual cells were boxed for data analysis. In some experiments, higher-magnification fields containing one to two cells $(256 \times 256 \mathrm{px}, 120.6 \mathrm{~nm} / \mathrm{px})$ were imaged. In both cases, the duration of each scan was $\sim 10 \mathrm{~s}$. Relative fluorescence $F$ at each time point $t$ was calculated as $100 \cdot\left(F_{\text {cell,t }}-F_{\text {bgd,to }}\right) /\left(F_{\text {cell,to }}-F_{\text {bgd,to }}\right)$, where $F_{\text {bgd,to }}$ was determined from an area in the first frame containing no cells. Cells in which fluorescence of free dsRed or GFP did not decrease after addition of digitonin, indicating poor permeabilization, were omitted.

\section{Experimental design and statistical analysis}

Microscopy images are representative examples of images from at least two independent experiments. For FPP assays, results from multiple wells from at least three independent experiments were combined.

\section{Results}

TRPM1 in ON-BPC bodies and axons is intracellular

To examine the location of TRPM1 in ON-BPC bodies, mouse retina sections were labeled with an antibody for 
A
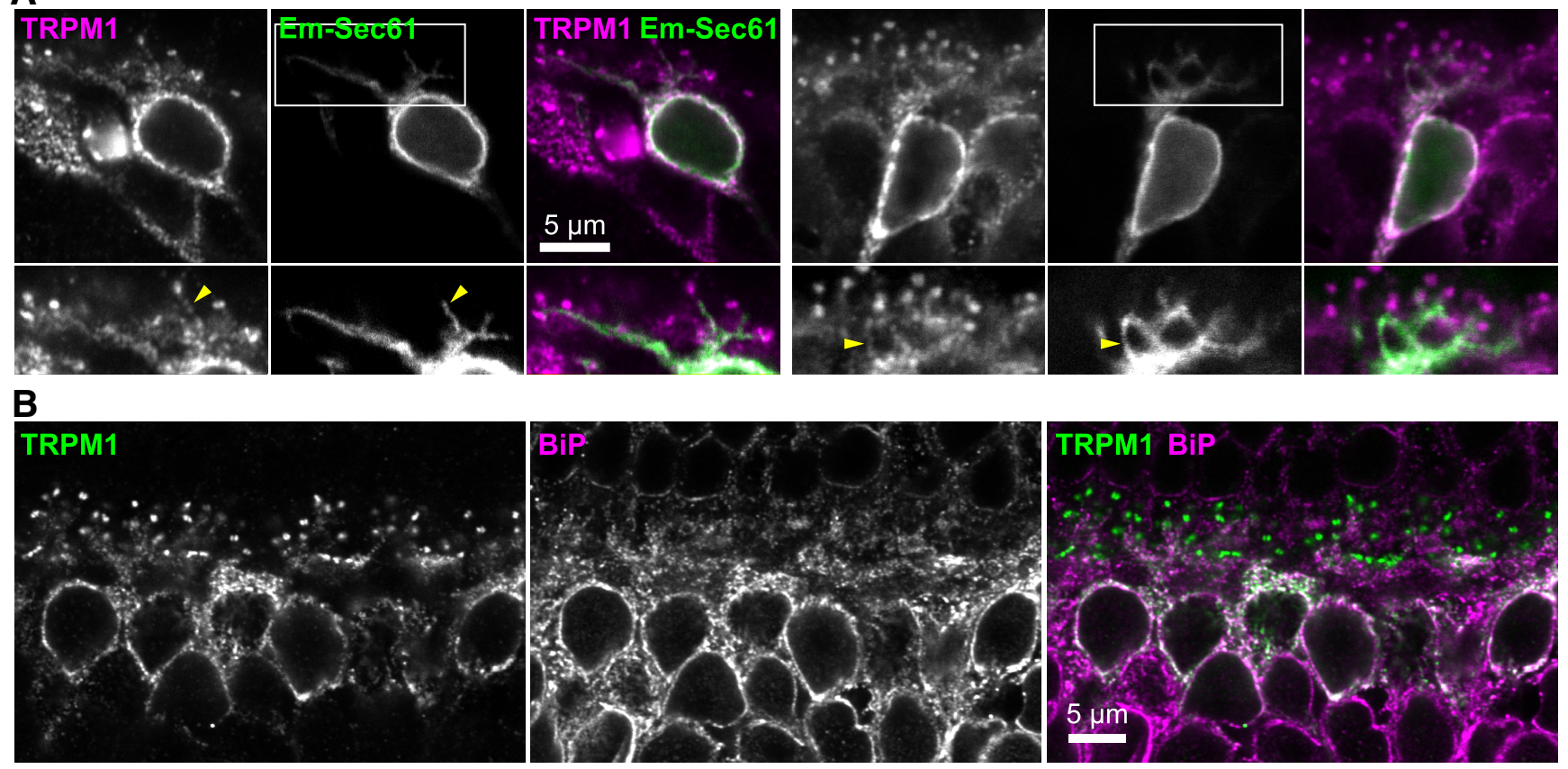

C

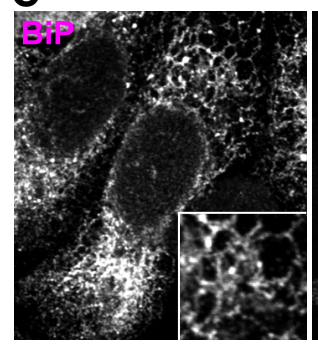

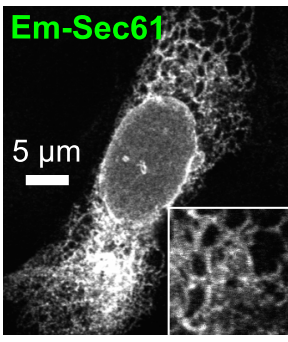

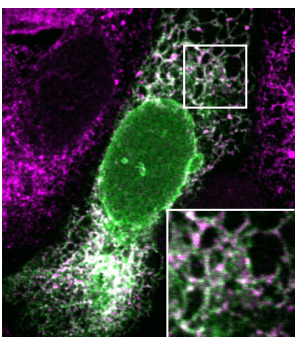

D
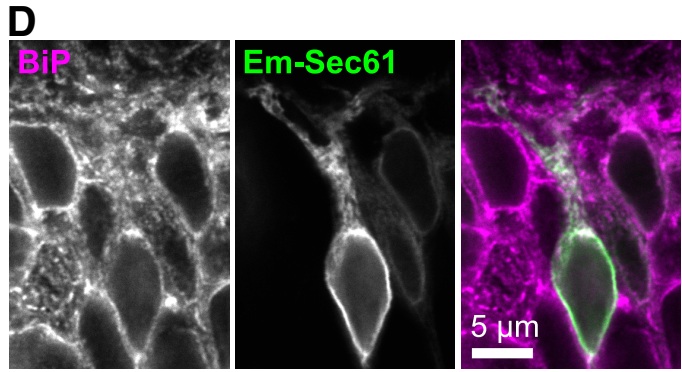

E $\mathrm{BiP}$
$250-$
$150-$
$100-$
$75^{-}-$
$50-$
$37-$

Figure 5. TRPM1 colocalizes with ER in ON-BPCs. A, Sections from retinas expressing Emerald-Sec61 $\beta$ in ON-BPCs were immunostained with TRPM1 antibody (magenta). Boxes indicate regions of higher-magnification images (bottom). Colocalization is observed in cell bodies, and in some cases, dendrites (arrowheads). B, Retina sections were immunostained with TRPM1 (green) and $\mathrm{BiP}$ (magenta) antibodies. $\boldsymbol{C}-\boldsymbol{E}$, Validation of BiP antibody. $\boldsymbol{C}, \mathrm{BiP}$ immunostaining colocalizes with transfected Emerald-Sec61 $\beta$ in $\mathrm{CHO}$ cells. $\boldsymbol{D}$, BiP immunostaining colocalizes with Emerald-Sec61 $\beta$ in sections from injected retinas. $\boldsymbol{E}$, Western blotting of retina lysate $(25 \mu \mathrm{g})$ probed with BiP antibody results in a band of the expected size ( $75 \mathrm{kDa}$; Munro and Pelham, 1986).

TRPM1 that was previously validated with Trpm1 knockout mice (Agosto et al., 2014, 2018), and antibodies for $\mathrm{Na}^{+} / \mathrm{K}^{+}$ATPase, a marker for plasma membranes, or $\operatorname{PKC} \alpha$, a soluble cytoplasmic protein well characterized as a marker for rod BPCs. In cell bodies, there was little or no colocalization of TRPM1 with $\mathrm{Na}^{+} / \mathrm{K}^{+}$ATPase, with TRPM1 appearing to be mostly intracellular (Fig. 1B). Labeling intensity was measured along lines drawn through the boundaries between cells; in most cases, the peak TRPM1 staining was noncoincident with the peak $\mathrm{Na}^{+} / \mathrm{K}^{+}$ATPase staining (Fig. 1B). To more clearly resolve the TRPM1 location in cell bodies, we employed STORM (Rust et al., 2006; Dempsey et al., 2011). STORM reconstructions of retina sections labeled with TRPM1 and $\mathrm{Na}^{+} / \mathrm{K}^{+}$ATPase antibodies clearly show non-overlapping staining in the cell bodies (Fig. 1C).

Furthermore, if TRPM1 were localized to the plasma membrane, staining would be expected to be peripheral to $\mathrm{PKC} \alpha$. However, TRPM1 staining was mostly internal relative to $\mathrm{PKC} \alpha$ in cell bodies (Fig. 1D). These results indicate that the majority of TRPM1 in cell bodies is located in intracellular membranes, and not in the plasma membrane. Column average intensity profiles of straightened axon segments show that TRPM1 labeling is mostly internal relative to both $\mathrm{Na}^{+} / \mathrm{K}^{+}$ATPase (Fig. 2A) and PKC $\alpha$ (Fig. 2B) in axons as well.

\section{Heterologously expressed TRPM1 colocalizes with the ER}

To determine the intracellular localization of TRPM1, we first examined the localization of heterologously-expressed protein. In both HEK293 and $\mathrm{CHO}$ cells transiently cotransfected with TRPM1 and Emerald-Sec61 $\beta$, an ER membrane marker (Huang et al., 2016; Rapoport et al., 2017), extensive colocalization was observed throughout the ER network (Fig. $3 A, B$ ). TRPM1 staining also colocalized with antibody staining for endogenous binding immunoglobulin protein (BiP; Fig. 3C), which resides in the ER lumen and is involved in protein folding (Rapoport et al., 2017). 
A
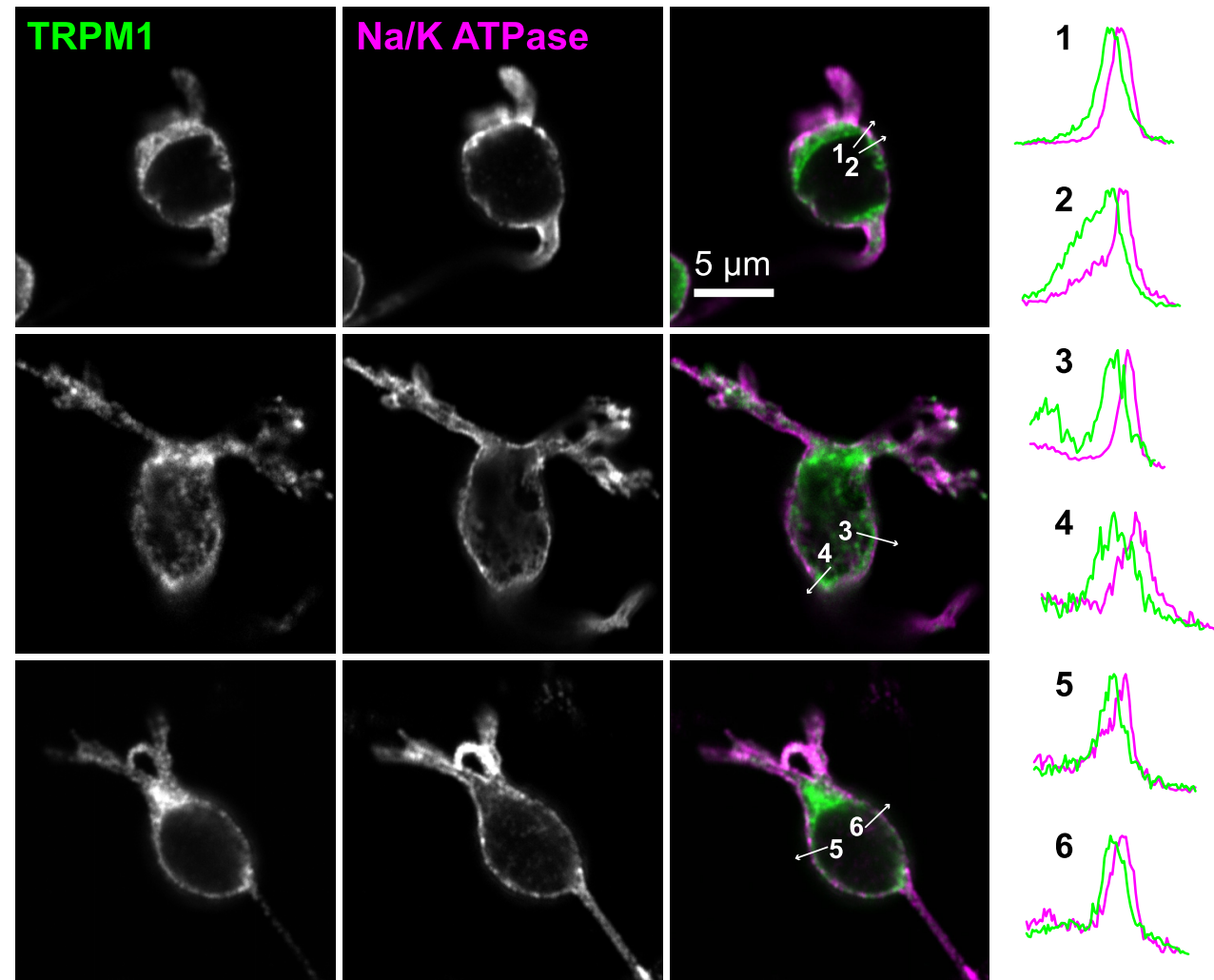

B
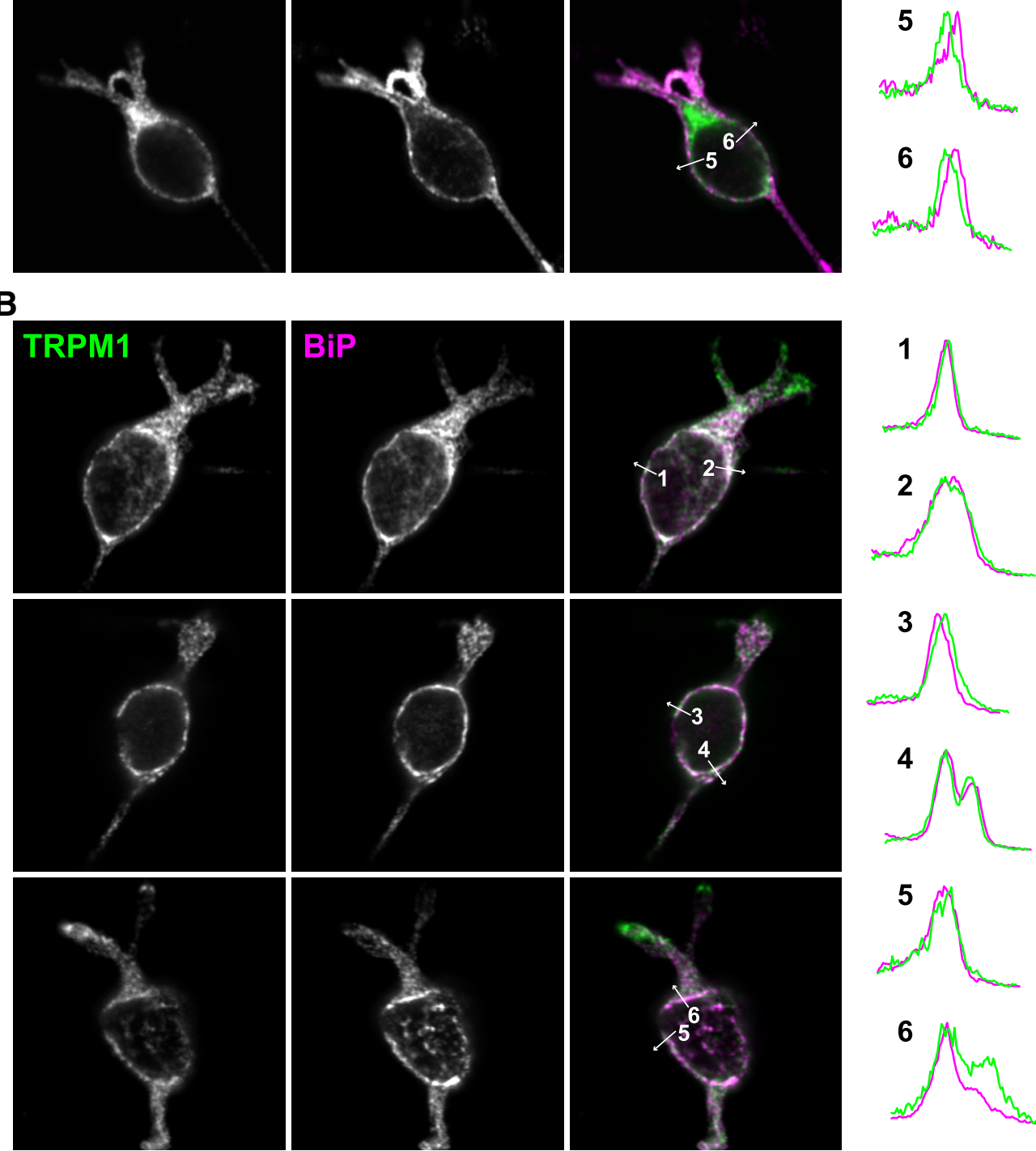

Figure 6. TRPM1 is intracellular and colocalized with ER in dissociated ON-BPCs. Acutely dissociated retinas were immunostained for TRPM1 (green) and $\mathrm{Na}^{+} / \mathrm{K}^{+}$ATPase $(\boldsymbol{A})$ or BiP $(\boldsymbol{B}$; magenta). Intensity profiles were measured along lines indicated by the arrows on the merged image, and are shown normalized to the maximum height. 
A
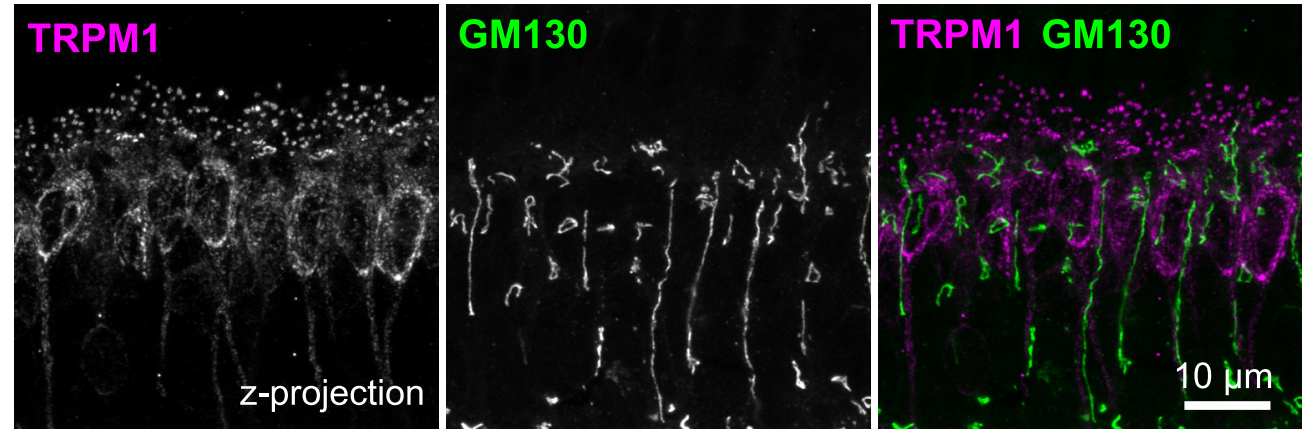

B
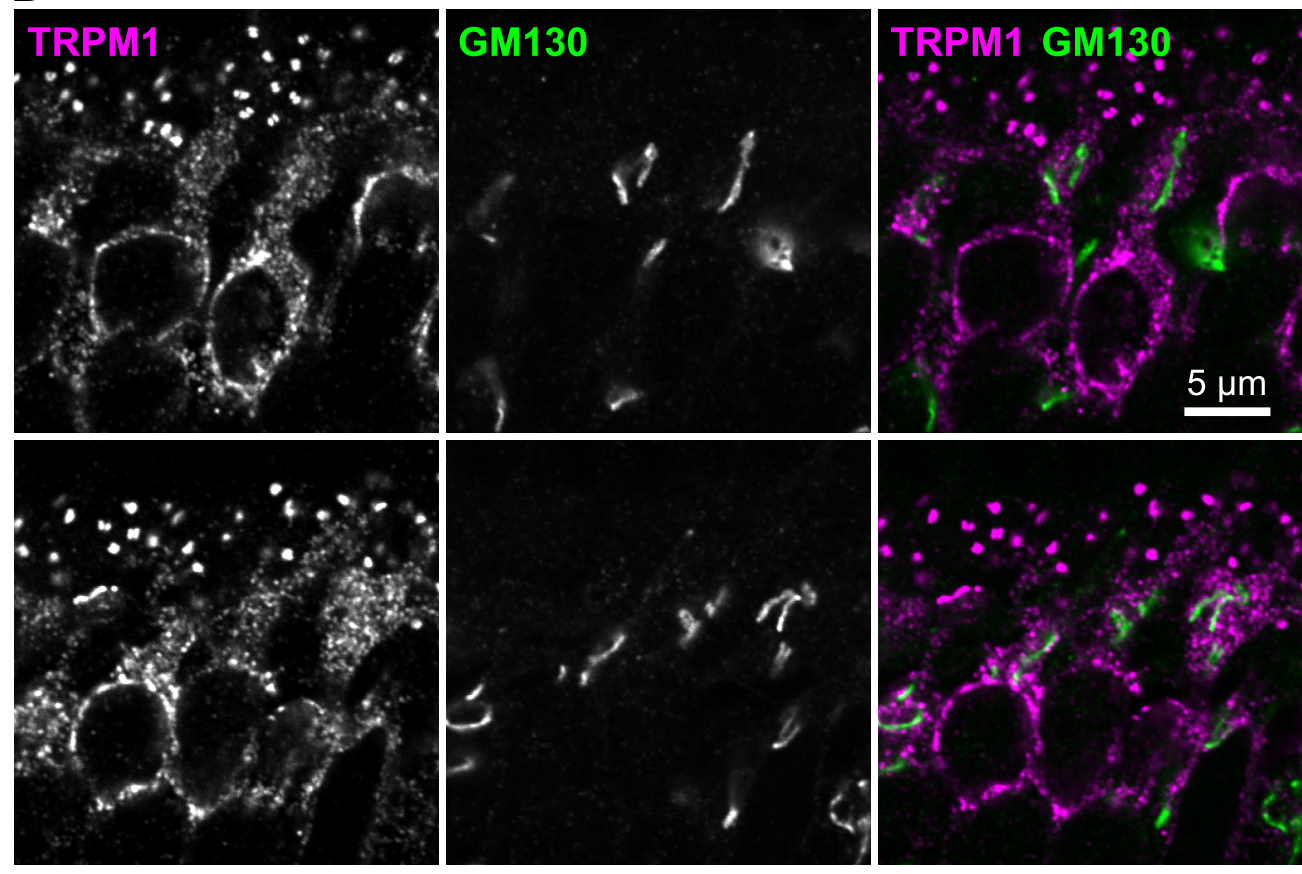

\section{C}
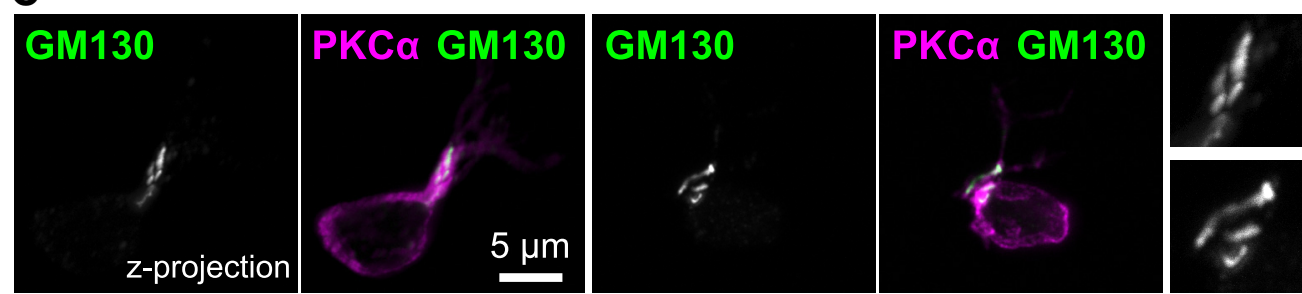

Figure 7. TRPM1 does not colocalize with Golgi in ON-BPCs. A, B, Retina sections were immunostained for TRPM1 (magenta) and cis-Golgi marker GM130 (green). C, To confirm the localization of Golgi in ON-BPCs, acutely dissociated retina cells were immunostained for PKC $\alpha$ (magenta) and GM130 (green). Zoomed-in views of GM130-labeled structures are shown at right.

\section{ER in ON-BPCs extends into axons and dendrites, but not dendritic tips}

Little is known about the location of secretory pathway organelles, including the ER, in ON-BPCs. Immunostaining ER markers is challenging, because most cells have an extensive ER network and staining appears throughout the retina (Johnson et al., 2007; also see Fig. 5B), giving rise to extensive background signal from neighboring cells. Therefore, subretinal injection and electroporation of Emerald-Sec61 $\beta$ under control of the mGluR6 pro- moter (Matsuda and Cepko, 2004; Kim et al., 2008; Lagali et al., 2008; Van Wyk et al., 2015) were employed to specifically and sparsely label ON-BPCs with an ER marker (Fig. 4). Z-stack projections show EmeraldSec61 $\beta$ localization throughout the cell bodies, dendrites, and axons of transduced cells (Fig. $4 A$ ). Even in cells with relatively weak expression of EmeraldSec61 $\beta$, signal is present in axons and dendrites (Fig. $4 A$, left), indicating the presence of ER in those compartments. Lacy structures characteristic of the ER 
A

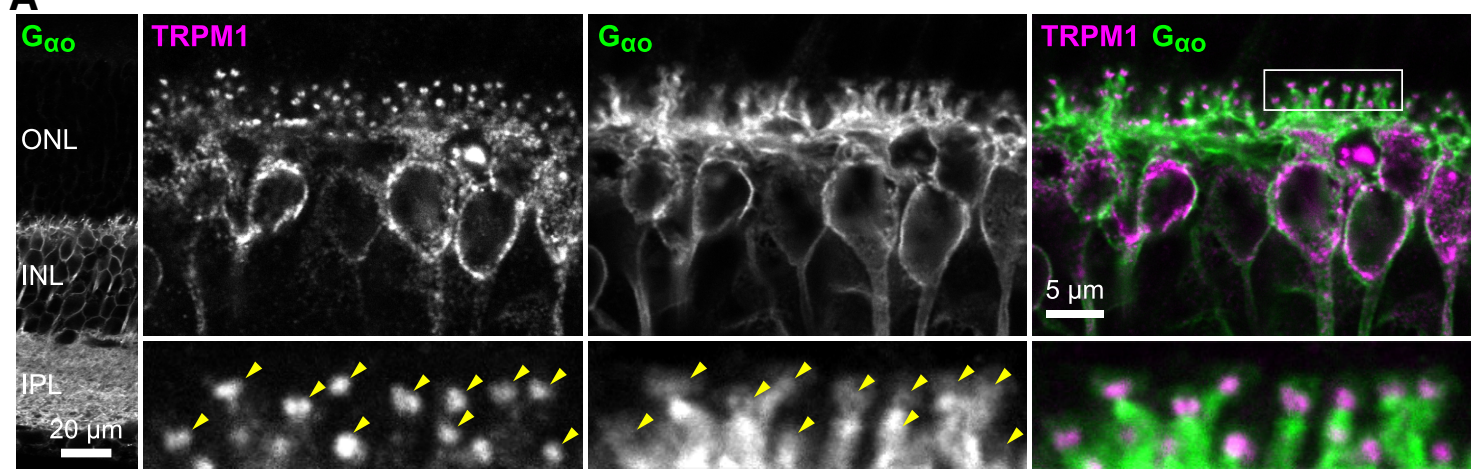

B

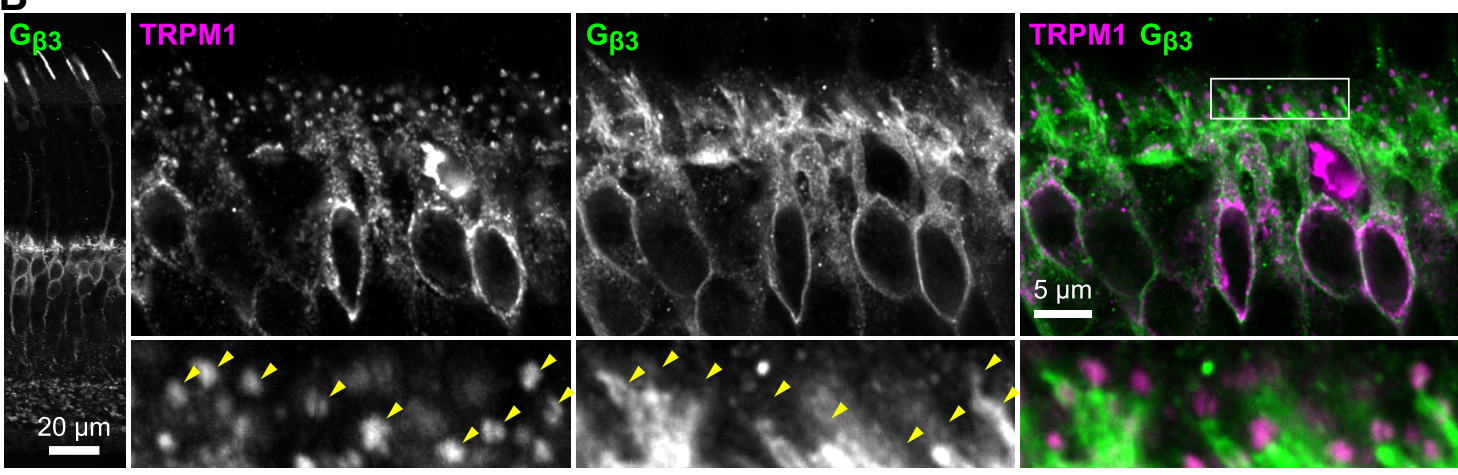

C
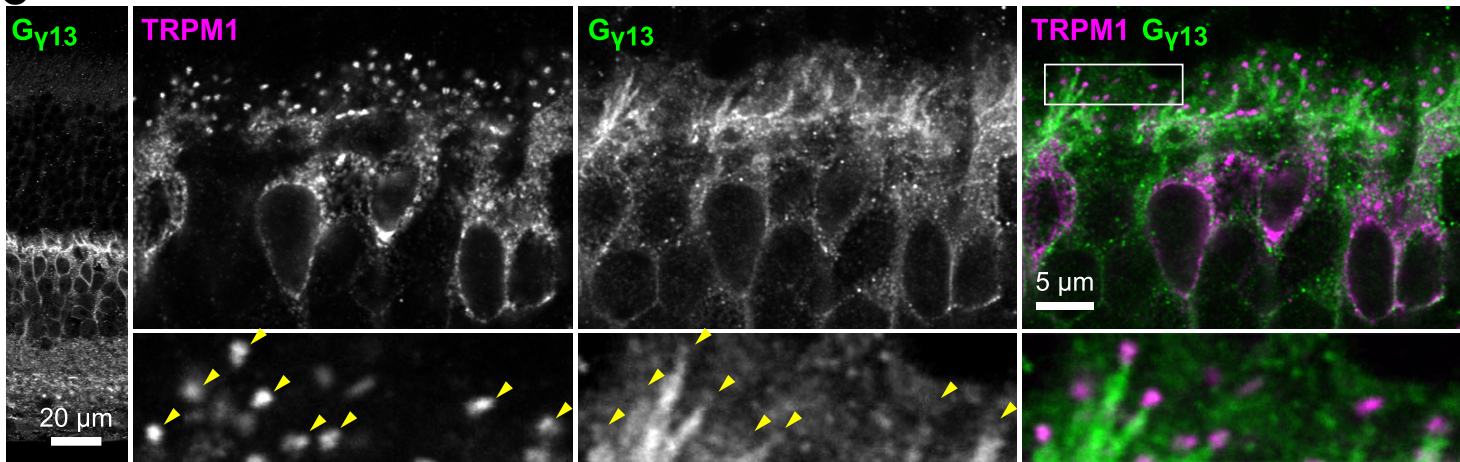

Figure 8. G protein subunits are poorly colocalized with TRPM1. Retina sections were immunostained for TRPM1 (magenta) and $\mathrm{G}_{\alpha \mathrm{o}}$ $(\boldsymbol{A}), \mathrm{G}_{\beta 3}(\boldsymbol{B})$, or $\mathrm{G}_{\gamma 13}(\boldsymbol{C}$; green). Low-magnification images are shown at left, and boxed regions are shown in magnified views below. Arrowheads indicate dendritic tip puncta.

network can be seen in higher-magnification images (Fig. 4B), and Emerald-Sec61 $\beta$ largely colocalized with the endogenous ER protein BiP (Fig. 5D). Labeling sections with $\mathrm{PKC} \alpha$ antibody showed that as with TRPM1, Emerald-Sec61 $\beta$ in cell bodies is internal to PKC $\alpha$ (Fig. 4C).

To examine dendritic tips, we generated a monoclonal antibody against full-length mGluR6. This antibody labels dendritic tips as expected, and labeling is absent in Grm6 ${ }^{\text {nob3 }}$ retina, which does not express mGluR6 protein (Maddox et al., 2008), demonstrating the specificity of the antibody (Fig. 4D). Labeling sections from injected retinas with mGluR6 antibody revealed no colocalization between Sec61 $\beta$ and mGluR6, indicating that the ER in dendrites does not extend into the dendritic tips (Fig. 4E). This is in contrast to $\mathrm{PKC} \alpha$, which can be seen clearly in the dendritic tip puncta (Fig. 1D, arrowheads).

\section{TRPM1 colocalizes with the ER in ON-BPC bodies}

Sections from Emerald-Sec61 $\beta$-injected retinas labeled with TRPM1 antibody show that in the cell bodies, TRPM1 largely colocalizes with the ER (Fig. 5A). In some cases, TRPM1 and Emerald-Sec61 $\beta$ also appear to colocalize in the dendritic shafts (Fig. $5 A$, arrowheads), although detection of TRPM1 in dendritic shafts is not reliable. To corroborate the ER localization of TRPM1, we costained retina sections with antibody for the ER lumen protein $\mathrm{BiP}$ (Fig. 5B). Validation of this antibody is shown in Figure $5 C-E$. The limited validation data for ER marker antibodies in retina tissue, as well as the fact that much of the ER labeling originates from other cell types not expressing TRPM1, makes the staining patterns difficult to interpret. However, in ON-BPC bodies there is at least partial colocalization of BiP with TRPM1, consistent with the the results from Emerald-Sec61 $\beta$-injected retinas. There is no 
A

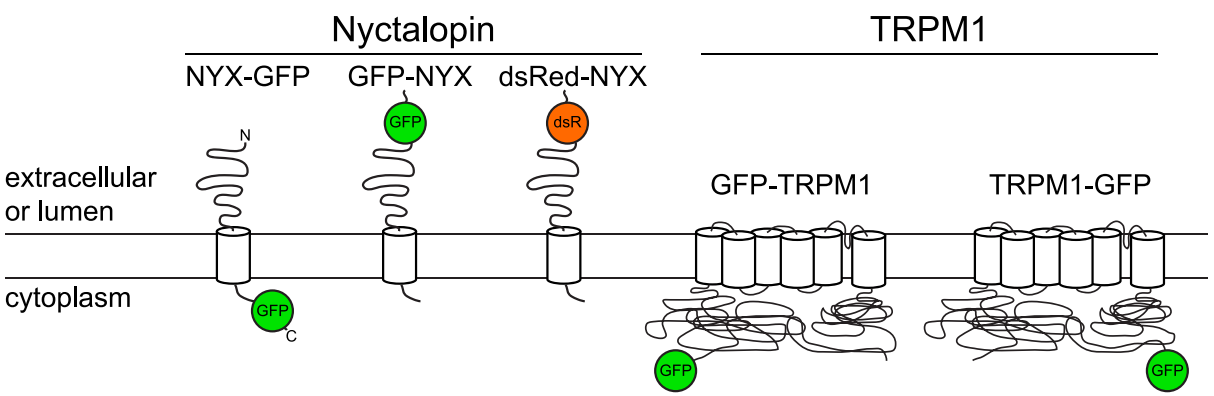

B
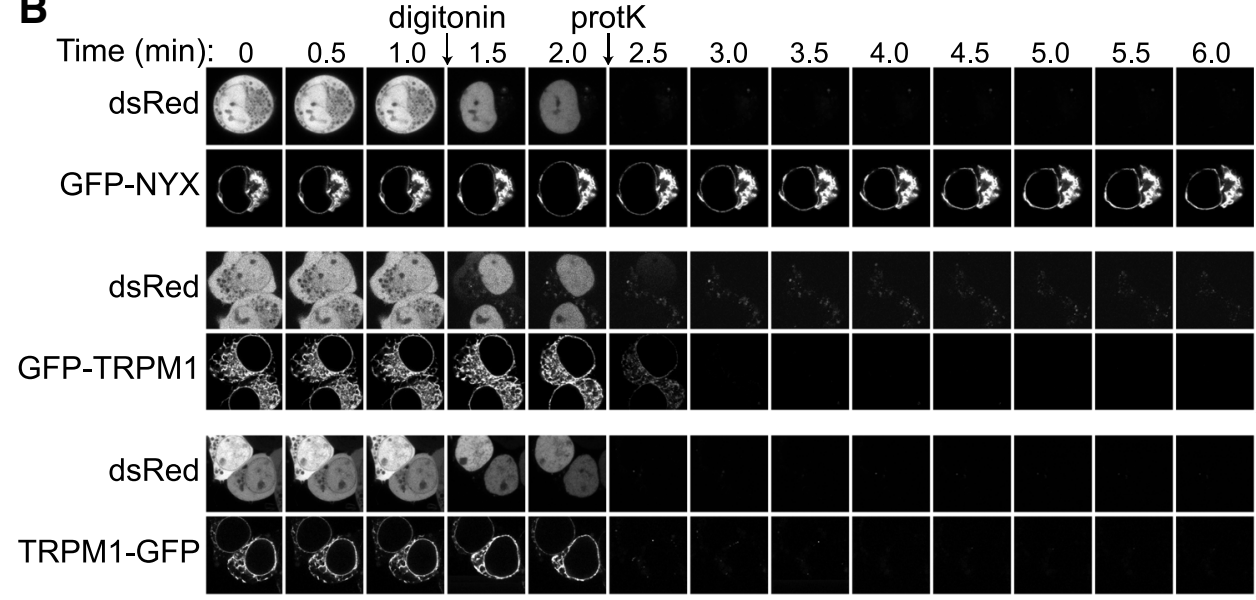

C

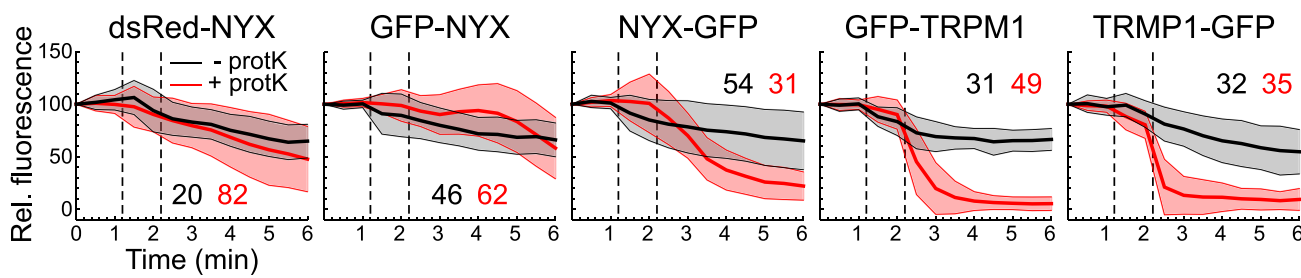

Figure 9. Topological analysis of heterologously expressed TRPM1. $\boldsymbol{A}$, Diagram of NYX and TRPM1 fluorescent fusions. $\boldsymbol{B}$, Example imaging timecourses of live cells. In some samples, cells were cotransfected with free dsRed to monitor digitonin action. On addition of digitonin to permeabilize the plasma membrane without disruption of the ER, dsRed diffuses rapidly out of the cytoplasm, then subsequently out of the nucleus. The fluorescence of GFP-NYX is resistant to proteinase K, implying GFP and the NYX N terminus are in the ER lumen, whereas that of GFP-TRPM1 and TRPM1-GFP is susceptible, revealing a cytoplasmic location for both C- and $\mathrm{N}$-terminal GFP fusions. $\boldsymbol{C}$, Cells from image timecourses as in $\boldsymbol{B}$, as well as cells boxed from lower-magnification images, were combined, and fluorescence expressed as a percentage of the initial signal. Curves are the means of results from the number of cells indicated, with shaded regions representing mean $\pm 1 \mathrm{SD}$. Dashed lines following the 1- and 2-min time points indicate the approximate time of addition of digitonin and proteinase $\mathrm{K}$, respectively.

clear evidence of ER labeling in the ON-BPC dendritic tips, consistent with the absence of Emerald-Sec61 $\beta$ in the tips (Fig. 4E). Since interpreting immunostaining of ON-BPCs in retina sections may be complicated by the presence of other cell types, we also examined isolated ON-BPCs in acutely dissociated retina preparations (Fig. 6). Costaining with $\mathrm{Na}^{+} / \mathrm{K}^{+}$ATPase confirmed largely intracellular somatic TRPM1 (Fig. $6 A$ ), which was partially colocalized with endogenous BiP (Fig. 6B), consistent with our previous observations.

\section{Golgi localization in ON-BPCs}

Immunostaining retina sections for the cis-Golgi marker GM130 (Nakamura et al., 1995) revealed filamentous or tubular structures throughout the inner nuclear layer, presumably present in various cell types (Fig. $7 A$ ); in $\mathrm{ON}$ -
BPCs, GM130 appears to be detected mainly in the distal cell body and dendritic trunk region (Fig. 7B). The location of GM130 in ON-BPCs was confirmed in the absence of other cell types by immunostaining acutely dissociated retinal cells (Fig. $7 C$ ). There was no colocalization with TRPM1 (Fig. 7B).

\section{G protein subunits poorly colocalize with TRPM1}

Heterotrimeric $G$ protein subunits $G_{\alpha 0}, G_{\beta 3}$, and $G_{\gamma 13}$ participate in the postsynaptic mGluR6 cascade in ONBPCs (Dhingra et al., 2000, 2002, 2012; Huang et al., 2003; Ramakrishnan et al., 2015), and both $G_{\alpha}$ and $G_{\beta \gamma}$ have been implicated in directly regulating TRPM1 (Koike et al., 2010a, 2010b; Shen et al., 2012; Xu et al., 2016). Although all three subunits are present in ON-BPC bodies and dendrites, there appears to be little colocalization 
with TRPM1 (Fig. 8) except in the dendritic tips, where $G_{\alpha o}$ is present (Fig. $8 A$, arrowheads). $\mathrm{G}_{\beta 3}$ and $\mathrm{G}_{\gamma 13}$ immunostaining was not sufficiently clear to confidently visualize them in the dendritic tips (Fig. 8B,C, arrowheads).

\section{TRPM1 $\mathbf{N}$ and $\mathrm{C}$ termini are cytoplasmic}

Limited sequence similarity between the transmembrane (TM) domain of TRPM1 and those of other TRP family channels suggests that TRPM1 has six TM helices (Agosto et al., 2014; Guo et al., 2017). However, no experimental data regarding the topology of the protein have been reported, and different TM prediction algorithms yield varying results. A FPP assay (Lorenz et al., 2006; Tie et al., 2012; Nixon et al., 2013), in conjunction with live cell imaging, was used to assess the membrane topology of TRPM1 and NYX (Fig. 9). HEK293 cells expressing GFP fusion proteins were treated with the detergent digitonin to permeabilize the plasma membrane selectively without disrupting the ER, followed by proteinase $\mathrm{K}$ treatment to digest regions accessible to the cytoplasm. If the terminus fused to GFP is in the cytoplasm, it should be rapidly digested, measured as a decrease in fluorescence, whereas if the terminus is in the ER lumen, it should be protected from digestion. Mouse NYX, which is known to have an extracellular or ER-luminal $\mathrm{N}$ terminus and a cytoplasmic C terminus (Bojang and Gregg, 2012), was used as a control. As expected, the fluorescence of cells expressing NYX-GFP decreased rapidly on addition of protease, while that of cells expressing GFP-NYX or dsRed-NYX was resistant for several minutes. The fluorescence of cells expressing TRPM1 with GFP at either the $\mathrm{N}$ or the $\mathrm{C}$ terminus was sensitive to protease treatment, indicating cytoplasmic accessibility of both termini, consistent with an even number of transmembrane segments, almost certainly six, as found in TRP channels with known structures.

\section{Discussion}

Our results demonstrate that TRPM1 in ON-BPC bodies is intracellular and located predominantly in the ER, and not the plasma membrane or Golgi apparatus (Figs. 1, 2, $5-7)$. This intracellular localization suggests that TRPM1 is inserted at the plasma membrane either in the dendrites or at the dendritic tips where it is concentrated. The subcellular localization of TRPM1 in dendritic shafts could not be determined, as TRPM1 signal is very poorly detected in dendrites, except at the dendritic tips. However, one hypothesis is that TRPM1 is trafficked all the way to the dendritic tips in the secretory pathway, where forward trafficking and/or plasma membrane insertion is triggered by a signal from a synapse-specific component. This hypothesis is consistent with the observations that knocking out other synaptic components reduces TRPM1 dendritic tip localization (Cao et al., 2011, 2015; Pearring et al., 2011; Xu et al., 2012; Gregg et al., 2014; Neuillé et al., 2015), if a correctly-formed synaptic complex is a prerequisite for TRPM1 plasma membrane insertion.

In other types of neurons, dendrites contain ER network, ER to Golgi intermediate compartments, and sometimes Golgi outposts. Synaptic proteins are trafficked by diverse secretory routes (for review, see Kennedy and
Ehlers, 2006; Ramírez and Couve, 2011; Valenzuela and Perez, 2015) including long-haul transport or diffusion within dendritic ER (Cui-Wang et al., 2012; Valenzuela et al., 2014) and Golgi-independent secretory trafficking (Bowen et al., 2017). Secretory pathways in retinal BPCs are still relatively unexplored. We show that the exogenously-expressed ER protein Sec61 $\beta$ is present in somas, axons, and dendrites (Fig. 4), indicating that, as in other neurons, the ER network in retinal BPCs extends into axons and dendrites. The two ER markers employed, endogenous BiP and electroporated Sec61 $\beta$, appear to have overlapping but nonidentical distributions, likely reflecting the heterogeneous nature of the ER. The widespread localization of TRPM1 in somas and axons (Figs. $1,2)$ suggests that it may diffuse freely in a continuous ER network membrane. The identities of organelles participating in post-ER trafficking, and the signals that direct plasma membrane insertion, are unknown.

Also mysterious is the large ER pool of TRPM1. It may reflect merely an excess of trafficking or assembly intermediates; it would not be surprising to find biosynthetic intermediates of membrane proteins in the ER. On the other hand, the distribution of TRPM1 is notably different from other transmembrane participants in the synaptic signaling pathway, with more than half found in the cell bodies (Agosto et al., 2018). An alternative explanation is that TRPM1 may have a distinct function in the ER membrane. In melanocytes, functional roles for intracellular TRPM1 in melanin synthesis and calcium homeostasis have been reported (Oancea et al., 2009; Devi et al., 2009, 2013). The related TRPM channels TRPM2 (Lange et al., 2009; Manna et al., 2015) and TRPM8 (Bidaux et al., 2015) have also been shown to have intracellular functions. Like TRPM1, the heterotrimeric G protein subunits mediating synaptic transduction reside partially in cell bodies. However, no obvious colocalization was observed with somatic TRPM1 (Fig. 8), suggesting that if ER-resident TRPM1 does have a function, it may not depend on $G_{\alpha o}$, $\mathrm{G}_{\beta 3}$, or $\mathrm{G}_{\gamma 13}$.

TRPM1 is present in both rod and cone ON-BPC bodies (Fig. 1D, asterisks). Although the localization appears similar in all ON-BPCs costained with plasma membrane or ER markers, we did not specifically differentiate rod and cone BPCs. It is possible that these cells employ different routes and/or regulation of TRPM1 secretory trafficking or support different functions for intracellular TRPM1.

No trafficking signals have been identified yet in TRPM1. Cytoplasmic ER retention signals have been identified in numerous channel subunits including NMDA receptors (Standley et al., 2000; Scott et al., 2001, 2003), ATP-sensitive $\mathrm{K}^{+}$channels (Zerangue et al., 1999), voltage-dependent $\mathrm{Ca}^{2+}$ channels (Bichet et al., 2000), voltage-gated $\mathrm{Na}^{+}$channels (Zhang et al., 2008), and TRP channels (Köttgen et al., 2005). Topology analysis (Fig. 9) showed both $\mathrm{N}$ and $\mathrm{C}$ termini of TRPM1 are in the cytoplasm, as expected from structures of other TRP channels (Liao et al., 2013; Paulsen et al., 2015; Guo et al., 2017; Winkler et al., 2017; Autzen et al., 2018; Yin et al., 2018), and it is likely that one or both of the cytoplasmic arms contains sequences that direct and regulate forward traf- 
ficking. Deciphering sequence determinants of TRPM1 trafficking and its route to the dendritic tip plasma membrane will be important for understanding the maintenance of functional synapses in ON-BPCs.

\section{References}

Agosto MA, Zhang Z, He F, Anastassov IA, Wright SJ, McGehee J, Wensel TG (2014) Oligomeric state of purified transient receptor potential melastatin-1 (TRPM1), a protein essential for dim light vision. J Biol Chem 289:27019-27033. CrossRef Medline

Agosto MA, Anastassov IA, Wensel TG (2018) Differential epitope masking reveals synapse-specific complexes of TRPM1. Vis Neurosci 35:e001. CrossRef Medline

Anastassov IA, Wang W, Dunn FA (2017) Synaptogenesis and synaptic protein localization in the postnatal development of rod bipolar cell dendrites in mouse retina. J Comp Neurol 00:1-15. CrossRef

Audo I, Kohl S, Leroy BP, Munier FL, Guillonneau X, Mohand-Saïd S, Bujakowska K, Nandrot EF, Lorenz B, Preising M, Kellner U, Renner AB, Bernd A, Antonio A, Moskova-Doumanova V, Lancelot M, Poloschek CM, Drumare I, Defoort-Dhellemmes S, Wissinger B, et al. (2009) TRPM1 is mutated in patients with autosomalrecessive complete congenital stationary night blindness. Am J Hum Genet 85:720-729. CrossRef Medline

Autzen HE, Myasnikov AG, Campbell MG, Asarnow D, Julius D, Cheng Y (2018) Structure of the human TRPM4 ion channel in a lipid nanodisc. Science 359:228-232. CrossRef Medline

Beaudoin GMJ, Lee S-H, Singh D, Yuan Y, Ng Y-G, Reichardt LF, Arikkath J (2012) Culturing pyramidal neurons from the early postnatal mouse hippocampus and cortex. Nat Protoc 7:1741-1754. CrossRef Medline

Berntson A, Taylor WR, Morgans CW (2003) Molecular identity, synaptic localization, and physiology of calcium channels in retinal bipolar cells. J Neurosci Res 71:146-151. CrossRef Medline

Bichet D, Cornet V, Geib S, Carlier E, Volsen S, Hoshi T, Mori Y, De Waard M (2000) The I-II loop of the Ca 2+ channel alpha1 subunit contains an endoplasmic reticulum retention signal antagonized by the beta subunit. Neuron 25:177-190. CrossRef

Bidaux G, Borowiec A, Gordienko D, Beck B, Shapovalov GG, Lemonnier L, Flourakis M, Vandenberghe M, Slomianny C, Dewailly E, Delcourt P, Desruelles E, Ritaine A, Polakowska R, Lesage J, Chami M, Skryma R, Prevarskaya N (2015) Epidermal TRPM8 channel isoform controls the balance between keratinocyte proliferation and differentiation in a cold-dependent manner. Proc Natl Acad Sci USA 112:E3345-E3354. CrossRef

Bock H, Geisler C, Von Middendorff C, Jakobs S, Schonle A, Egner A, Hell SW, Eggeling C (2007) Two-color far-field fluorescence nanoscopy based on photoswitchable emitters. Appl Phys B 88: 161-165. CrossRef

Bojang P, Gregg RG (2012) Topological analysis of small leucine-rich repeat proteoglycan nyctalopin. PLoS One 7:e33137. CrossRef Medline

Bowen AB, Bourke AM, Hiester BG, Hanus C, Kennedy MJ (2017) Golgi-independent secretory trafficking through recycling endosomes in neuronal dendrites and spines. Elife 6:e27362. CrossRef

Cao Y, Posokhova E, Martemyanov KA (2011) TRPM1 forms complexes with nyctalopin in vivo and accumulates in postsynaptic compartment of ON-bipolar neurons in mGluR6-dependent manner. J Neurosci 31:11521-11526. CrossRef

Cao Y, Sarria I, Fehlhaber KE, Kamasawa N, Orlandi C, James KN, Hazen JL, Gardner MR, Farzan M, Lee A, Baker S, Baldwin K, Sampath AP, Martemyanov KA (2015) Mechanism for selective synaptic wiring of rod photoreceptors into the retinal circuitry and its role in vision. Neuron 87:1248-1260. CrossRef Medline

Concepcion F, Chen J (2010) Q344ter mutation causes mislocalization of rhodopsin molecules that are catalytically active: a mouse model of Q344ter-induced retinal degeneration. PLoS One 5:e10904. CrossRef Medline
Consalvi S, Brancaccio A, Dall'Agnese A, Puri PL, Palacios D (2017) Praja1 E3 ubiquitin ligase promotes skeletal myogenesis through degradation of EZH2 upon $\mathrm{p} 38 \alpha$ activation. Nat Commun 8:13956. CrossRef

Cui-Wang T, Hanus C, Cui T, Helton T, Bourne J, Watson D, Harris KM, Ehlers MD (2012) Local zones of endoplasmic reticulum complexity confine cargo in neuronal dendrites. Cell 148:309-321. CrossRef Medline

Dempsey GT, Vaughan JC, Chen KH, Bates M, Zhuang X (2011) Evaluation of fluorophores for optimal performance in localizationbased super-resolution imaging. Nat Methods 8:1027-1036. CrossRef Medline

Devi S, Kedlaya R, Maddodi N, Bhat KMR, Weber CS, Valdivia H, Setaluri V (2009) Calcium homeostasis in human melanocytes: role of transient receptor potential melastatin 1 (TRPM1) and its regulation by ultraviolet light. Am J Physiol Cell Physiol 297:C679C687. CrossRef

Devi S, Markandeya Y, Maddodi N, Dhingra A, Vardi N, Balijepalli RC, Setaluri V (2013) Metabotropic glutamate receptor 6 signaling enhances TRPM1 calcium channel function and increases melanin content in human melanocytes. Pigment Cell Melanoma Res 26: 348-356. CrossRef Medline

Dhingra A, Lyubarsky A, Jiang M, Pugh EN, Birnbaumer L, Sterling P, Vardi N (2000) The light response of ON bipolar neurons requires G[alpha]o. J Neurosci 20:9053-9058. CrossRef

Dhingra A, Jiang M, Wang T-L, Lyubarsky A, Savchenko A, BarYehuda T, Sterling P, Birnbaumer L, Vardi N (2002) Light response of retinal $\mathrm{ON}$ bipolar cells requires a specific splice variant of $\mathrm{G} \alpha \mathrm{O}$. J Neurosci 22:4878-4884. CrossRef

Dhingra A, Ramakrishnan H, Neinstein A, Fina ME, Xu Y, Li J, Chung DC, Lyubarsky A, Vardi N (2012) G $\beta 3$ is required for normal light ON responses and synaptic maintenance. J Neurosci 32:1134311355. CrossRef Medline

Dunn FA, Wong ROL (2014) Wiring patterns in the mouse retina: collecting evidence across the connectome, physiology and light microscopy. J Physiol 592:4809-4823. CrossRef

Giménez E, Montoliu L (2001) A simple polymerase chain reaction assay for genotyping the retinal degeneration mutation (Pdeb rd1) in FVB/N-derived transgenic mice. Lab Anim 35:153-156. CrossRef Medline

Gregg RG, Ray TA, Hasan N, McCall MA, Peachey NS (2014) Interdependence among members of the mGluR6 G-protein mediated signalplex of retinal depolarizing bipolar cells. In: $G$ protein signaling mechanisms in the retina (Martemyanov KA, Sampath AP, eds), pp 67-79. New York: Springer.

Guo J, She J, Zeng W, Chen Q, Bai X, Jiang Y (2017) Structures of the calcium-activated, non-selective cation channel TRPM4. Nature 552:205-209. CrossRef Medline

Han F, Liu C, Zhang L, Chen M, Zhou Y, Qin Y, Wang Y, Chen M, Duo S, Cui X, Bao S, Gao F (2017) Globozoospermia and lack of acrosome formation in GM130-deficient mice. Cell Death Dis 8:e2532. CrossRef Medline

Han TK, Everett RS, Proctor WR, Ng CM, Costales CL, Brouwer KLR, Thakker DR (2013) Organic cation transporter 1 (OCT1/mOct1) is localized in the apical membrane of Caco-2 cell monolayers and enterocytes. Mol Pharmacol 84:182-189. CrossRef Medline

Heilemann M, van de Linde S, Schüttpelz M, Kasper R, Seefeldt B, Mukherjee A, Tinnefeld P, Sauer M (2008) Subdiffractionresolution fluorescence imaging with conventional fluorescent probes. Angew Chem Int Ed Engl 47:6172-6176. CrossRef Medline

Hodges RS, Heaton RJ, Parker JMR, Molday L, Molday RS (1988) Antigen-antibody interaction. Synthetic peptides define linear antigenic determinants recognized by monoclonal antibodies directed to the cytoplasmic carboxyl terminus of rhodopsin. J Biol Chem 263:11768-11775. Medline

Huang F, Sirinakis G, Allgeyer ES, Schroeder LK, Duim WC, Kromann EB, Phan T, Rivera-Molina FE, Myers JR, Irnov I, Lessard M, Zhang Y, Handel MA, Jacobs-Wagner C, Lusk CP, Rothman JE, Toomre 
D, Booth MJ, Bewersdorf J (2016) Ultra-high resolution 3D imaging of whole cells. Cell 166:1028-1040. CrossRef Medline

Huang L, Max M, Margolskee RF, Su H, Masland RH, Euler T (2003) $G$ protein subunit $G$ gamma 13 is coexpressed with $G$ alpha $0, G$ beta 3 , and $\mathrm{G}$ beta 4 in retinal $\mathrm{ON}$ bipolar cells. J Comp Neur 455:1-10. CrossRef Medline

Hubler D, Rankovic M, Richter K, Lazarevic V, Altrock WD, Fischer D, Gundelfinger ED, Fejtova A (2012) Differential spatial expression and subcellular localization of CtBP family members in rodent brain. PLoS One 7:e39710. CrossRef

Huynh KW, Cohen MR, Jiang J, Samanta A, Lodowski DT, Zhou ZH, Moiseenkova-Bell VY (2016) Structure of the full-length TRPV2 channel by cryo-EM. Nat Commun 7:11130. CrossRef Medline

Iwai-Takekoshi L, Ramos A, Schaler A, Weinreb S, Blazeski R, Mason C (2016) Retinal pigment epithelial integrity is compromised in the developing albino mouse retina. J Comp Neur 524: 3696-3716. CrossRef Medline

Johnson JE, Perkins GA, Giddabasappa A, Chaney S, Xiao W, White AD, Brown JM, Waggoner J, Ellisman MH, Fox DA (2007) Spatiotemporal regulation of ATP and $\mathrm{Ca} 2+$ dynamics in vertebrate rod and cone ribbon synapses. Mol Vis 13:887-919. Medline

Kennedy MJ, Ehlers MD (2006) Organelles and trafficking machinery for postsynaptic plasticity. Annu Rev Neurosci 29:325-362. CrossRef Medline

Kim DS, Matsuda T, Cepko CL (2008) A core paired-type and POU homeodomain-containing transcription factor program drives retinal bipolar cell gene expression. J Neurosci 28:7748-7764. CrossRef Medline

Koh H-J, Kim Y-R, Kim J-S, Yun J-S, Jang K, Yang C-S (2017) Toxoplasma gondii GRA7-targeted ASC and PLD1 promote antibacterial host defense via PKC $\alpha$. PLoS Pathog 13:e1006126. CrossRef Medline

Koike C, Numata T, Ueda H, Mori Y, Furukawa T (2010a) TRPM1: a vertebrate TRP channel responsible for retinal ON bipolar function. Cell Calcium 48:95-101. CrossRef Medline

Koike C, Obara T, Uriu Y, Numata T, Sanuki R, Miyata K, Koyasu T, Ueno S, Funabiki K, Tani A, Ueda H, Kondo M, Mori Y, Tachibana M, Furukawa T (2010b) TRPM1 is a component of the retinal ON bipolar cell transduction channel in the mGluR6 cascade. Proc Natl Acad Sci USA 107:332-337. CrossRef Medline

Köttgen M, Benzing T, Simmen T, Tauber R, Buchholz B, Feliciangeli S, Huber TB, Schermer B, Kramer-Zucker A, Höpker K, Simmen KC, Tschucke CC, Sandford R, Kim E, Thomas G, Walz G (2005) Trafficking of TRPP2 by PACS proteins represents a novel mechanism of ion channel regulation. EMBO J 24:705-716. CrossRef Medline

Lagali PS, Balya D, Awatramani GB, Münch TA, Kim DS, Busskamp V, Cepko CL, Roska B (2008) Light-activated channels targeted to ON bipolar cells restore visual function in retinal degeneration. Nat Neurosci 11:667-675. CrossRef Medline

Lambert S, Drews A, Rizun O, Wagner TFJ, Lis A, Mannebach S, Plant S, Portz M, Meissner M, Philipp SE, Oberwinkler J (2011) Transient receptor potential melastatin 1 (TRPM1) is an ionconducting plasma membrane channel inhibited by zinc. J Biol Chem 286:12221-12233. CrossRef

Lange I, Yamamoto S, Partida-Sanchez S, Mori Y, Fleig A, Penner R (2009) TRPM2 functions as a lysosomal Ca2+-release channel in $\beta$ cells. Sci Signal 2:ra23. CrossRef Medline

Li X, Mumby SM, Greenwood A, Jope RS (1995) Pertussis toxinsensitive $\mathrm{G}$ protein alpha-subunits: production of monoclonal antibodies and detection of differential increases on differentiation of PC12 and LA-N-5 cells. J Neurochem 64:1107-1117. CrossRef

Li Z, Sergouniotis PI, Michaelides M, Mackay DS, Wright GA, Devery S, Moore AT, Holder GE, Robson AG, Webster AR (2009) Recessive mutations of the gene TRPM1 abrogate ON bipolar cell function and cause complete congenital stationary night blindness in humans. Am J Hum Genet 85:711-719. CrossRef Medline

Liao M, Cao E, Julius D, Cheng Y (2013) Structure of the TRPV1 ion channel determined by electron cryo-microscopy. Nature 504: 107-112. CrossRef Medline
Lorenz H, Hailey DW, Wunder C, Lippincott-Schwartz J (2006) The fluorescence protease protection (FPP) assay to determine protein localization and membrane topology. Nat Protoc 1:276-279. CrossRef

Lu Q, Ivanova E, Ganjawala TH, Pan Z-H (2013) Cre-mediated recombination efficiency and transgene expression patterns of three retinal bipolar cell-expressing Cre transgenic mouse lines. Mol Vis 19:1310-1321. Medline

Mackenzie D, Arendt A, Hargrave P, McDowell JH, Molday RS (1984) Localization of binding sites for carboxyl terminal specific antirhodopsin monoclonal antibodies using synthetic peptides. Biochemistry 23:6544-6549. Medline

Macrez N, Morel J-L, Mironneau J (1999) Specific Galpha11beta3gamma5 protein involvement in endothelin receptor-induced phosphatidylinositol hydrolysis and $\mathrm{Ca} 2+$ release in rat portal vein myocytes. Mol Pharmacol 55:684-692. Medline

Maddox DM, Vessey KA, Yarbrough GL, Invergo BM, Cantrell DR, Inayat S, Balannik V, Hicks WL, Hawes NL, Byers S, Smith RS, Hurd R, Howell D, Gregg RG, Chang B, Naggert JK, Troy JB, Pinto LH, Nishina PM, McCall MA (2008) Allelic variance between GRM6 mutants, Grm6nob3 and Grm6nob4 results in differences in retinal ganglion cell visual responses. J Physiol 586:4409-4424. CrossRef Medline

Manna PT, Munsey TS, Abuarab N, Li F, Asipu A, Howell G, Sedo A, Yang W, Naylor J, Beech DJ, Jiang L-H, Sivaprasadarao A (2015) TRPM2-mediated intracellular $\mathrm{Zn} 2+$ release triggers pancreatic $\beta$-cell death. Biochem J 466:537-546. CrossRef Medline

Martemyanov KA, Sampath AP (2017) The transduction cascade in retinal ON-bipolar cells: signal processing and disease. Annu Rev Vis Sci 3:25-51. CrossRef Medline

Masu M, Iwakabe H, Tagawa Y, Miyoshi T, Yamashita M, Fukuda Y, Sasaki H, Hiroi K, Nakamura Y, Shigemoto R, Takada M, Nakamura K, Nakao K, Katsuki M, Nakanishi S (1995) Specific deficit of the $\mathrm{ON}$ response in visual transmission by targeted disruption of the mGluR6 gene. Cell 80:757-765. Medline

Matsuda T, Cepko CL (2004) Electroporation and RNA interference in the rodent retina in vivo and in vitro. Proc Natl Acad Sci USA 101:16-22. CrossRef Medline

Matsuda T, Cepko CL (2008) Analysis of gene function in the retina. Methods Mol Biol 423:259-278. CrossRef Medline

Mattapallil MJ, Wawrousek EF, Chan C-C, Zhao H, Roychoudhury J, Ferguson TA, Caspi RR (2012) The rd8 mutation of the Crb1 gene is present in vendor lines of C57BL/6N mice and embryonic stem cells, and confounds ocular induced mutant phenotypes. Invest Ophthalmol Vis Sci 53:2921-2927. CrossRef Medline

Molday RS, MacKenzie D (1983) Monoclonal antibodies to rhodopsin: characterization, cross-reactivity, and application as structural probes. Biochemistry 22:653-660. Medline

Morgans CW, Ren G, Akileswaran L (2006) Localization of nyctalopin in the mammalian retina. Eur J Neurosci 23:1163-1171. CrossRef Medline

Morgans CW; Weiwei Liu, Wensel TG, Brown RL, Perez-Leon JA, Bearnot B, Duvoisin RM (2007) Gbeta5-RGS complexes colocalize with mGluR6 in retinal ON-bipolar cells. Eur J Neurosci 26:2899-2905. CrossRef Medline

Morgans CW, Zhang J, Jeffrey BG, Nelson SM, Burke NS, Duvoisin RM, Brown RL (2009) TRPM1 is required for the depolarizing light response in retinal ON-bipolar cells. Proc Natl Acad Sci USA 106:19174-19178. CrossRef Medline

Munro S, Pelham HRB (1986) An Hsp70-like protein in the ER: identity with the $78 \mathrm{kd}$ glucose-regulated protein and immunoglobulin heavy chain binding protein. Cell 46:291-300. Medline

Nakamura N, Rabouille C, Watson R, Nilsson T, Hui N, Slusarewicz $P$, Kreis TE, Warren G (1995) Characterization of a cis-Golgi matrix protein, GM130. J Cell Biol 131:1715-1726. Medline

Neuillé M, Morgans CW, Cao Y, Orhan E, Michiels C, Sahel J-A, Audo I, Duvoisin RM, Martemyanov KA, Zeitz C (2015) LRIT3 is essential to localize TRPM1 to the dendritic tips of depolarizing bipolar cells and may play a role in cone synapse formation. Eur $\mathrm{J}$ Neurosci 42:1966-1975. CrossRef Medline 
Nixon A, Jia Y, White C, Bradbury NA (2013) Determination of the membrane topology of lemur tyrosine kinase 2 (LMTK2) by fluorescence protease protection. Am J Physiol Cell Physiol 304: C164-C169. CrossRef Medline

Nomura A, Shigemoto R, Nakamura Y, Okamoto N, Mizuno N, Nakanishi S (1994) Developmentally regulated postsynaptic localization of a metabotropic glutamate receptor in rat rod bipolar cells. Cell 77:361-369. Medline

Oancea E, Vriens J, Brauchi S, Jun J, Splawski I, Clapham DE (2009) TRPM1 forms ion channels associated with melanin content in melanocytes. Sci Signal 2:ra21. CrossRef Medline

Olivier N, Keller D, Rajan VS, Gönczy P, Manley S (2013) Simple buffers for 3D STORM microscopy. Biomed Opt Express 4:885899. CrossRef Medline

Orlandi C, Cao Y, Martemyanov KA (2013) Orphan receptor GPR179 forms macromolecular complexes with components of metabotropic signaling cascade in retina ON-bipolar neurons. Invest Ophthalmol Vis Sci 54:7153-7161. CrossRef Medline

Park S, Kim S, Kim MJ, Hong Y, Young A, Lee AY, Lee H, Tran Q, Kim M, Cho H, Park J, Kim KP, Park J, Cho M-H (2018) GOLGA2 loss causes fibrosis with autophagy in the mouse lung and liver. Biochem Biophys Res Commun 495:594-600. CrossRef Medline

Paulsen CE, Armache J-P, Gao Y, Cheng Y, Julius D (2015) Structure of the TRPA1 ion channel suggests regulatory mechanisms. Nature 520:511-517. CrossRef Medline

Peachey NS, Pearring JN, Bojang P, Hirschtritt ME, Sturgill-Short G, Ray TA, Furukawa T, Koike C, Goldberg AFX, Shen Y, McCall MA, Nawy S, Nishina PM, Gregg RG (2012a) Depolarizing bipolar cell dysfunction due to a Trpm1 point mutation. J Neurophysiol 108: 2442-2451. CrossRef

Peachey NS, Ray TA, Florijn R, Rowe LB, Sjoerdsma T, ContrerasAlcantara S, Baba K, Tosini G, Pozdeyev N, luvone PM, Bojang P, Pearring JN, Simonsz HJ, van Genderen M, Birch DG, Traboulsi El, Dorfman A, Lopez I, Ren H, Goldberg AFX, et al. (2012b) GPR179 is required for depolarizing bipolar cell function and is mutated in autosomal-recessive complete congenital stationary night blindness. Am J Hum Genet 90:331-339. CrossRef

Pearring JN, Bojang P, Shen Y, Koike C, Furukawa T, Nawy S, Gregg $R G$ (2011) A role for nyctalopin, a small leucine-rich repeat protein, in localizing the TRP melastatin 1 channel to retinal depolarizing bipolar cell dendrites. J Neurosci 31:10060-10066. CrossRef Medline

Ramakrishnan H, Dhingra A, Tummala SR, Fina ME, Li JJ, Lyubarsky A, Vardi N (2015) Differential function of $\mathrm{G} \gamma 13$ in rod bipolar and ON cone bipolar cells. J Physiol 593:1531-1550. CrossRef Medline

Ramírez OA, Couve A (2011) The endoplasmic reticulum and protein trafficking in dendrites and axons. Trends Cell Biol 21:219-227. CrossRef Medline

Rapoport TA, Li L, Park E (2017) Structural and mechanistic insights into protein translocation. Annu Rev Cell Dev Biol 33:369-390. CrossRef Medline

Regus-Leidig H, Specht D, Tom Dieck S, Brandstätter JH (2010) Stability of active zone components at the photoreceptor ribbon complex. Mol Vis 16:2690-2700. Medline

Ribic A, Liu X, Crair MC, Biederer T (2014) Structural organization and function of mouse photoreceptor ribbon synapses involve the immunoglobulin protein synaptic cell adhesion molecule 1. J Comp Neur 522:900-920. CrossRef Medline

Robichaux MA, Potter VL, Zhang Z, He F, Schmid MF, Wensel TG (2017) Defining the layers of a sensory cilium with STORM and cryo-electron nanoscopies. bioRxiv doi:10.1101/198655.

Robillard KR, Hoque T, Bendayan R (2012) Expression of ATPBinding cassette membrane transporters in rodent and human Sertoli cells: relevance to the permeability of antiretroviral therapy at the blood-testis barrier. J Pharmacol Exp Ther 340:96-108. CrossRef Medline

Rust MJ, Bates M, Zhuang X (2006) Sub-diffraction-limit imaging by stochastic optical reconstruction microscopy (STORM). Nat Methods 3:793-795. CrossRef Medline
Schneider FM, Mohr F, Behrendt M, Oberwinkler J (2015) Properties and functions of TRPM1 channels in the dendritic tips of retinal ON-bipolar cells. Eur J Cell Biol 94:420-427. CrossRef Medline

Scott DB, Blanpied TA, Swanson GT, Zhang C, Ehlers MD (2001) An NMDA receptor ER retention signal regulated by phosphorylation and alternative splicing. J Neurosci 21:3063-3072. Medline

Scott DB, Blanpied TA, Ehlers MD (2003) Coordinated PKA and PKC phosphorylation suppresses RXR-mediated ER retention and regulates the surface delivery of NMDA receptors. Neuropharmacology 45:755-767. Medline

Shen Y, Heimel JA, Kamermans M, Peachey NS, Gregg RG, Nawy S (2009) A transient receptor potential-like channel mediates synaptic transmission in rod bipolar cells. J Neurosci 29:6088-6093. CrossRef

Shen Y, Rampino MAF, Carroll RC, Nawy S (2012) G-protein-mediated inhibition of the Trp channel TRPM1 requires the $G \beta \gamma$ dimer. Proc Natl Acad Sci USA 109:8752-8757. CrossRef Medline

Standley S, Roche KW, Mccallum J, Sans N, Wenthold RJ (2000) PDZ domain suppression of an ER retention signal in NMDA receptor NR1 splice variants. Neuron 28:887-898. Medline

Tie JK, Jin DY, Stafford DW (2012) Human vitamin K epoxide reductase and its bacterial homologue have different membrane topologies and reaction mechanisms. J Biol Chem 287:33945-33955. CrossRef Medline

Valenzuela JI, Perez F (2015) Diversifying the secretory routes in neurons. Front Neurosci 9:358. CrossRef Medline

Valenzuela JI, Jaureguiberry-Bravo M, Salas DA, Ramírez OA, Cornejo VH, Lu HE, Blanpied TA, Couve A (2014) Transport along the dendritic endoplasmic reticulum mediates the trafficking of GABAB receptors. J Cell Sci 127:3382-3395. CrossRef Medline

Van Genderen MM, Bijveld MMC, Claassen YB, Florijn RJ, Pearring $\mathrm{JN}$, Meire FM, Mccall MA, Riemslag FCC, Gregg RG, Bergen AAB, Kamermans M (2009) Mutations in TRPM1 are a common cause of complete congenital stationary night blindness. Am J Hum Genet 85:730-736. CrossRef

Van Wyk M, Pielecka-Fortuna J, Löwel S, Kleinlogel S (2015) Restoring the ON switch in blind retinas: opto-mGluR6, a nextgeneration, cell-tailored optogenetic tool. PLoS Biol 13:e1002143. CrossRef Medline

Winkler PA, Huang Y, Sun W, Du J, Lü W (2017) Electron cryomicroscopy structure of a human TRPM4 channel. Nature 552: 200-204. CrossRef Medline

Wong JP, Reboul E, Molday RS, Kast J (2009) A carboxy-terminal affinity tag for the purification and mass spectrometric characterization of integral membrane proteins. J Proteome Res 8:23882396. CrossRef

Xu Y, Dhingra A, Fina ME, Koike C, Furukawa T, Vardi N (2012) mGluR6 deletion renders the TRPM1 channel in retina inactive. $J$ Neurophysiol 107:948-957. CrossRef Medline

Xu Y, Orlandi C, Cao Y, Yang S, Choi C-I, Pagadala V, Birnbaumer L, Martemyanov KA, Vardi N (2016) The TRPM1 channel in ONbipolar cells is gated by both the $\alpha$ and the $\beta \gamma$ subunits of the G-protein Go. Sci Rep 6:20940. CrossRef Medline

Yin Y, Wu M, Zubcevic L, Borschel WF, Lander GC, Lee S-Y (2018) Structure of the cold- and menthol-sensing ion channel TRPM8. Science 359:237-241. CrossRef Medline

Zerangue N, Schwappach B, Jan YN, Jan LY (1999) A new ER trafficking signal regulates the subunit stoichiometry of plasma membrane K ATP channels. Neuron 22:537-548. Medline

Zhang Z-N, Li Q, Liu C, Wang H-B, Wang Q, Bao L (2008) The voltage-gated $\mathrm{Na}+$ channel Nav1.8 contains an ER-retention/retrieval signal antagonized by the beta3 subunit. J Cell Sci 121: 3243-3252. CrossRef Medline

Zhao D, Lu X, Wang G, Lan Z, Liao W, Li J, Liang X, Chen JR, Shah $S$, Shang $X$, Tang M, Deng P, Dey $P$, Chakravarti $D$, Chen $P$, Spring DJ, Navone NM, Troncoso P, Zhang J, Wang YA, et al. (2017) Synthetic essentiality of chromatin remodelling factor CHD1 in PTEN-deficient cancer. Nature 542:484-488. CrossRef Medline 